\title{
1. Traditional knowledge: why and how should we protect it?
}

Indigenous Peoples of the world have the right to self determination and in exer-

cising that right must be recognised as the exclusive owners of their cultural and intellectual property . . . Indigenous people are capable of managing their traditional knowledge themselves, but are willing to offer it to all humanity provided their fundamental rights to define and control this knowledge are protected by the international community. ${ }^{1}$

\section{A. INTRODUCTION}

Traditional knowledge is a highly valuable resource from a spiritual, cultural and economic perspective. ${ }^{2}$ Protecting traditional knowledge from misappropriation and exploitation not only prevents the continuing dispossession of Indigenous and local peoples but also may operate to secure economic benefits for Indigenous and local communities. As described by Daes:

Indigenous peoples cannot survive, or exercise their fundamental human rights as distinct nations, societies and peoples without the ability to conserve, revive, develop and teach the wisdom they have inherited from their ancestors. ${ }^{3}$

1 Mataatua Declaration on Cultural and Intellectual Property Rights of Indigenous Peoples, June 1993, Preamble.

2 Susette Biber-Klemm and Danuta Szymura Berglas, 'Problems and Goals' in Susette Biber-Klemm, Thomas Cottier and Danuta Szymura Berglas (eds), Rights to Plant Genetic Resources and Traditional Knowledge: Basic Issues and Perspectives (CAB International on behalf of the Swiss Agency for Development and Cooperation and the World Trade Institute, 2006) 3, 21; Graham Dutfield, 'Developing and Implementing National Systems for Protecting Traditional Knowledge: A Review of Experiences in Selected Developing Countries' (UNCTAD Expert Meeting on Systems and National Experiences for Protecting Traditional Knowledge, Innovations and Practices, 2000) 7; Krishna Ravi Srinivas, 'Traditional Knowledge and Intellectual Property Rights: A Note on Issues, Some Solutions and Some Suggestions' (2008) 3 Asian Journal WTO and International Health Law and Policy 81, 86.

3 Erica-Irene Daes, Study on the protection of the cultural and intellectual property of indigenous peoples, by Erica-Irene Daes, Special Rapporteur of the Sub-Commission on Prevention of Discrimination and Protection of Minorities and Chairperson of the Working Group on Indigenous Populations, UN Doc E/CN.4/Sub.2/1993/28 (28 July 1993) 4, [1]. 
The mechanism by which the protection of traditional knowledge can be achieved is the subject of much debate. However, the use of sui generis regimes for the protection of traditional knowledge is gaining traction at an international level. While questions remain as to how such regimes may be structured and implemented, access and benefit sharing regimes and databases have emerged as important strategies in the protection of traditional knowledge. Investigating how these strategies have been deployed in existing sui generis regimes for the protection of traditional knowledge in countries such as India and Peru provides a valuable opportunity to identify lessons that may inform the development of sui generis regimes in countries that are yet to implement specific protections for traditional knowledge.

The importance of traditional knowledge from a spiritual and cultural perspective is difficult to quantify. Traditional knowledge is a holistic concept that reflects the cultural relationship of Indigenous and local communities with their land and natural resources ${ }^{4}$ and cannot be separated from cultural identity. ${ }^{5}$ Not only does traditional knowledge meet the physical, subsistence, social, cultural and spiritual needs of Indigenous and local communities, ${ }^{6}$ it also strengthens cultural identity and institutions. ${ }^{7}$

This traditional knowledge is at risk of erosion as a consequence of the continuing impacts of colonisation, including bio-colonialism. ${ }^{8}$ As argued by Terri

4 Biotrade Initiative, 'UNCTAD BIOTRADE: Some considerations on Access, Benefit Sharing and Traditional Knowledge' (UNCTAD Expert Meeting on Systems and National Experiences for Protecting Traditional Knowledge, Innovations and Practices, 2000) 9.

5 Charles McManis and Yolanda Teran, 'Trends and scenarios in the legal protection of traditional knowledge' in Tzen Wong and Graham Dutfield (eds), Intellectual Property and Human Development: Current Trends and Future Scenarios (Cambridge University Press, 2011) 139, 141.

6 Biotrade Initiative, above $\mathrm{n} 4$.

7 Graham Dutfield, Protecting Traditional Knowledge: Pathways to the Future Issue Paper No 16 (ICTSD Programme on IPRs and Sustainable Development, 2006) ix.

8 Laurelyn Whitt, Science, Colonialism, and Indigenous Peoples: The Cultural Politics of Law and Knowledge (Cambridge University Press, 2009) 20, 23-4; Vandana Shiva, Biopiracy: The Plunder of Nature and Knowledge (North Atlantic Books, 2016) 1. Laurelyn Whitt defines 'bio-colonialism' as a 'variant of neo-colonialism, a relationship of dominance and oppression between nations or peoples in which a nation, or nations, maintains power over another nation through a variety of means other than direct governmental control.' Building on this concept, Whitt then defines 'extractive bio-colonialism' as 'any activity that (a) through the use of force or coercion (economic or otherwise) involves or facilitates the removal, processing, conversion into private property and commodification of indigenous genetic resources by agents of the dominant culture(s), and (b) typically results in some or all of the following: 1. substantial damage to the environment, such that a peoples' way of life is destroyed, undermined 
Janke, the continuing misappropriation and exploitation of traditional knowledge, without prior informed consent or sharing of benefits, is culturally inappropriate and is leading to the destruction of cultural heritage and knowledge: ${ }^{9}$

Indigenous Australians are concerned that their knowledge is being appropriated without their consent or knowledge and for little or nothing in return. The commercialisation of Indigenous intellectual and cultural property has often been done without respect for Indigenous cultures, without consent or legal Indigenous control and without sharing of benefits with Indigenous communities. Indigenous cultural heritage has often been distorted for commercial interests. This in turn is leading to its erosion. ${ }^{10}$

In addition to the spiritual and cultural damage arising in consequence of this misappropriation and exploitation, there is a lost financial opportunity for Indigenous and local peoples to develop businesses based on their knowledge. While Indigenous and local communities do not view traditional knowledge solely as a commodity to be traded, ${ }^{11}$ traditional knowledge is also of significant economic value. Approximately 80 per cent of the world's population relies on traditional medicine for their primary health care needs. ${ }^{12}$ Furthermore, where plants are used in prescription medicines, it is estimated that approximately 75 per cent of those plants were originally used in traditional medicine. ${ }^{13}$ Traditional knowledge may, therefore, represent a significant resource for companies engaged in pharmaceutical or agricultural

or threatened; 2. erosion of indigenous health and well-being, whether physical or spiritual; 3. destabilization of indigenous social, economic and legal structures; 4 . creation of new, or the exacerbation of existing, internal or external political struggles; 5. disruption or discrediting of indigenous knowledge and value systems; 6 . imposition of concepts, practices, and values that further the economic and political interests of the dominant culture; 7. loss of political and economic autonomy, and increased dependency on the dominant culture(s); and 8. assimilation and loss of biological and cultural diversity.'

9 Terri Janke, 'Respecting Indigenous Cultural and Intellectual Property Rights' (1999) 22(2) University of New South Wales Law Journal 631, 632.

10 Ibid.

11 Statement by the International Indigenous Forum on Biodiversity cited in Conference of the Parties to the Convention on Biological Diversity, Report of the Seventh Meeting of the Conference of the Parties to the Convention on Biological Diversity, UN Doc UNEP/CBD/COP/7/21 (13 April 2004) [585]-[588].

12 Katrina Brown, 'Medicinal Plants, indigenous medicine and conservation of biodiversity in Ghana' in Timothy M. Swanson (ed), Intellectual Property Rights and Biodiversity Conservation: An Interdisciplinary Analysis of the Values of Medicinal Plants (Cambridge University Press, 1995) 201.

13 Jack Kloppenburg Jr, 'No Hunting! Biodiversity, Indigenous Rights and Scientific Poaching' (1991) 15(3) Cultural Survival Quarterly 14. 
research and development and may be used to drive cost savings. ${ }^{14}$ Statistics suggest that the use of traditional knowledge may increase the efficiency of screening plant resources for medicinal purposes by more than 400 per cent. ${ }^{15}$ The value of the world market for medicinal products derived from leads associated with traditional knowledge is estimated at approximately USD 43 billion. ${ }^{16}$ It is further estimated that benefits of approximately USD 5.4 billion would flow to Indigenous and local communities around the world if multinational corporations paid royalties for traditional knowledge used in food, agriculture and pharmaceuticals. ${ }^{17}$

It is in recognition of the economic value of biological resources and associated traditional knowledge and the role such knowledge plays in the conservation of biological diversity that the Convention on Biological Diversity ('CBD') ${ }^{18}$ establishes an access and benefit-sharing regime to facilitate use of traditional knowledge and provide incentives for commercialisation. ${ }^{19}$ The Nagoya Protocol on Access to Genetic Resources and the Fair and Equitable Sharing of Benefits Arising from their Utilization to the Convention on Biological Diversity ('Nagoya Protocol') ${ }^{20}$ implements the ABS obligations arising out of the CBD and specifically addresses access to traditional knowl-

14 Vandana Shiva, Biopiracy: The Plunder of Nature and Knowledge (South End Press, 1997) 11-16; Henrietta Fourmile-Marrie, 'Developing a Regime to Protect Indigenous Traditional Biodiversity-Related Knowledge' (2000) 1 Balayi 163, 163; Michael Blakeney, What is Traditional Knowledge? Why Should it be Protected? Who Should Protect it? For Whom?: Understanding the Value Chain, WIPO Doc WIPO/ IPTK/RT/99/3 (6 October 1999) 9.

15 Michael J. Balick 'Ethnobotany and the Identification of Therapeutic Agents from the Rainforest' in Derek J. Chadwick and Joan Marsh (eds), Bioactive Compounds from Plants (Wiley-Interscience, 1990) 22; Erica-Irene Daes, Protection of the Heritage of Indigenous People (United Nations, 1997) 12; Katie O'Bryan, 'The Appropriation of Indigenous Ecological Knowledge: Recent Australian Developments' (2004) 1 Macquarie Journal of International and Comparative Environmental Law 29, 32.

${ }_{16}$ Darrell Posey, 'Intellectual Property Rights and Just Compensation for Indigenous Knowledge' (1990) 6(4) Anthropology Today 13, 15; Andrew Gray 'Indigenous Peoples and the Marketing of the Rainforest' (1990) 20(6) The Ecologist 223, 226.

17 United Nations Development Programme and Rural Advancement Foundation International, Conserving Indigenous Knowledge: Integrating two systems of innovation (Rural Advancement Foundation International, 1994) 17.

18 Convention on Biological Diversity, opened for signature 5 June 1992, 1760 UNTS 30619 (entered into force 29 December 1993) ('CBD').

19 Susette Biber-Klemm and Danuta Szymura Bergas, above n 2, 21.

20 Nagoya Protocol on Access to Genetic Resources and the Fair and Equitable Sharing of Benefits Arising from their Utilization to the Convention on Biological Diversity, opened for signature 2 February 2011, UNEP/CBD/COP/DEC/X/1 (entered into force 12 October 2014) ('Nagoya Protocol'). 
edge associated with genetic resources. Even though some argue that the value of traditional knowledge as a source of leads for pharmaceutical and agricultural products is declining, ${ }^{21}$ or is not as great as originally estimated,,$^{22}$ traditional knowledge may still form the foundation for innovation by commercial interests, and by Indigenous and local communities themselves, for the benefit of all humanity. ${ }^{23}$ The continued use and exploitation of traditional knowledge is indicative of its commercial value ${ }^{24}$ and it is likely such exploitation and misappropriation will continue unless measures are established to protect traditional knowledge and ensure that use of traditional knowledge occurs with the prior informed consent of the Indigenous or local community involved and fair and equitable sharing of the benefits arising from such use.

Indigenous and local peoples have suffered many wrongs, including murder, enslavement, rape, torture, theft and forced relocation, ${ }^{25}$ along with the historical and ongoing suppression of institutions in Indigenous and local communities that positively affirm Indigenous values, cultures and identities. ${ }^{26}$ These wrongs are ongoing and represent the continuing legacy of colonisation or conquest. Rights in traditional knowledge may be used, among other tools, as a form of corrective justice to empower Indigenous and local communities and return modern and contemporary institutions that affirm and support Indigenous values and practices. ${ }^{27}$ Furthermore, protecting against acts of biopiracy will help prevent further loss of traditional knowledge and culture. As argued by Daes, the protection of traditional knowledge is 'connected fundamentally with the realization of the territorial rights and self-determination of indigenous peoples. ${ }^{28}$

21 Graham Dutfield, above n 7, 4.

22 Ibid.

23 Secretariat, World Intellectual Property Organization, Protection of Traditional Knowledge: Overview of Policy Objectives and Core Principles, Doc No WIPO/ GRTKF/IC/7/5 (20 August 2004).

${ }^{24}$ Michael Dodson and Olivia Barr, 'Breaking the Deadlock: Developing an Indigenous Response to Protecting Indigenous Traditional Knowledge' (2007) 11 Australian Indigenous Law Review 19, 24.

25 Stephen R. Munzer, 'Corrective justice and intellectual property rights in traditional knowledge' in Annabelle Lever (ed), New Frontiers in the Philosophy of Intellectual Property (Cambridge University Press, 2012) 58, 58.

26 Douglas Sanderson, 'Redressing the Right Wrong: The Argument from Corrective Justice' (2012) 62 University of Toronto Law Journal 93, 93.

27 Ibid.

28 Erica-Irene Daes, Study on the protection of the cultural and intellectual property of indigenous peoples, by Erica-Irene Daes, Special Rapporteur of the Sub-Commission on Prevention of Discrimination and Protection of Minorities and Chairperson of the Working Group on Indigenous Populations, UN Doc E/CN.4/Sub.2/1993/28 (28 July 1993) 4, [1]. 
A number of options for the protection of traditional knowledge have been studied over recent decades. This book argues that the use of sui generis regimes is the most appropriate solution to the misappropriation and exploitation of traditional knowledge. ${ }^{29}$ Sui generis regimes based on the principles of self-determination, prior informed consent and mutually agreed terms can empower Indigenous and local peoples to make decisions regarding the use and protection of traditional knowledge and ensure that benefits are returned to Indigenous and local communities. The use of sui generis regimes is supported by the Conference of the Parties to the CBD and the World Intellectual Property Organization, ${ }^{30}$ and a number of countries-including India and Peru $^{31}$ - have implemented their own sui generis regimes for the protection of traditional knowledge. Although there has been criticism of sui generis regimes the comparative analysis set out in this book will demonstrate positive ways in which sui generis regimes can be used to protect traditional knowledge and meet the needs and expectations of Indigenous and local peoples around the world.

While the Nagoya Protocol entered into force in 2014, a number of countries are grappling with how to implement their obligations particularly with respect to the protection of traditional knowledge. In so doing, it is essential to examine how foreign jurisdictions have approached the issue and learn from their experience. This book presents a detailed comparative analysis of the regimes of

29 See Natalie P. Stoianoff and Alpana Roy, 'Indigenous Knowledge and Culture in Australia-The Case for Sui Generis Legislation' (2015) 41 Monash University Law Review 745.

30 Conference of the Parties to the Convention on Biological Diversity, Decision VIII/5: Article 8(j) and related provisions, Doc No UNEP/CBD/COP/DEC/VIII/5 (15 June 2006), accessed 3 November 2019 at https:/www.cbd.int/doc/decisions/cop-08/ cop-08-dec-05-en.pdf; World Intellectual Property Organization General Assembly, Matters Concerning the Intergovernmental Committee on Intellectual Property and Genetic Resources, Traditional Knowledge and Folklore, 38th (19th Ordinary) sess, Agenda Item 28, UN Doc WIPO/GRTKF/IC/15/REF-DECISION 28 (1 October 2009).

31 Biological Diversity Act 2002 (India); Law 27811 Introducing a Protection Regime for the Collective Knowledge of Indigenous Peoples Derived from Biological Resources 2002 (Peru); Indigenous Peoples Rights Act of 1997 (Philippines); Decree Law No. 118 of 2002 Establishing a Legal Regime of Registration, Conservation, Legal Custody and Transfer of Plant Endogenous Material (Portugal); Law No. 7788 of 1998 on Biodiversity (Costa Rica); Provisional Measure No. 2186-16 of 2001 Regulating Access to the Genetic Heritage, Protection of and Access to Associated Traditional Knowledge (Brazil); Law No. 13,123 of 20 May 2015 (Access and Benefits Sharing of Genetic Resources and Associated Traditional Knowledge) (Brazil); The Protection of Traditional Knowledge, Genetic Resources and Expressions of Folklore Act 2016 (Zambia). 
India ${ }^{32}$ and Peru $^{33}$ for the protection of traditional knowledge across four key themes: history and objectives; institutions and funding; access and benefit sharing; and databases. The comparative analysis identifies the key features, similarities and differences and assesses the implementation of each regime. The outcomes of the comparative analysis are interpreted within a framework of self-determination and legal pluralism. By interpreting the outcomes of the comparative analysis within a framework of self-determination and pluralism, the book takes into account different legal systems-including the conflict between individual and collective rights - and promotes the incorporation of customary law and practice into any proposal for the protection of traditional knowledge. The book also identifies lessons from the experience of India and Peru that could inform the design and implementation of frameworks for the protection of traditional knowledge in other countries. Chapter 6 uses Australia as an illustrative example of how these lessons may be applied in a domestic context. The lessons identified in Chapter 6 are intended to stimulate discussion and may be used by Indigenous and local peoples in the development of a sui generis regime for the protection of traditional knowledge. In order to provide context for the analysis set out in this book, this chapter explains why traditional knowledge should be protected, the existing international regimes that provide some measure of protection for traditional knowledge, and the role of sui generis regimes in the protection of traditional knowledge.

\section{B. TERMINOLOGY}

The book uses working definitions of 'traditional knowledge' and 'Indigenous and local peoples' to frame the scope of the inquiry noting however that these definitions remain contested for reasons outlined in further detail below. The author recognises and supports the right of Indigenous people and local communities to make decisions regarding the definition, identification and protection of their knowledge.

32 In particular, the following legislation: Biological Diversity Act 2002; Biological Diversity Rules 2004; Patents Act 1970.

33 In particular, the following legislation: Law No. 27811 Introducing a Protection Regime for the Collective Knowledge of Indigenous Peoples Derived from Biological Resources 2002; Law No. 28216 Act on the Protection of Access to Peruvian Biological Diversity and the Collective Knowledge of Indigenous Peoples 2004. 


\section{Traditional Knowledge}

The concept of traditional knowledge has been the subject of much debate over the past three decades and the term may be 'easier to comprehend than define'. ${ }^{34}$ Despite many attempts to define traditional knowledge, at both international and domestic levels, there is no universally accepted definition. Accordingly, the terminology used varies depending on the context, with differing terms used in the fields of heritage, biodiversity and conservation, human rights, and intellectual property ${ }^{35}$ For example, traditional knowledge has variously been described as 'expressions of folklore', ${ }^{36}$ traditional 'knowledge, innovations and practices', ${ }^{37}$ 'traditional ecological knowledge', ${ }^{38}$ 'indigenous cultural and intellectual property' ${ }^{39}$ and, more simply, 'traditional knowledge' ${ }^{40}$

The difficulty in reaching agreement on terminology can be attributed in part to the fact that traditional knowledge as a subject matter is not a uniform concept, and the use of any one term may not appropriately recognise the diversity of Indigenous and local communities and cultures at a global, regional and national level. ${ }^{41}$ Indeed, Dodson and Barr question the value in defining the term traditional knowledge and suggest that it may be in the best interests of Indigenous and local communities to leave the term undefined. ${ }^{42}$

Operating within the framework of conservation and sustainable use of biological diversity, the CBD refers to the 'knowledge, innovations and prac-

34 Intellectual Property Rights Policy for Kerala 2008 (Kerala, India) [2], accessed 3 November 2019 at http://www.wipo.int/wipolex/en/text.jsp?file_id=200374.

35 Secretariat, World Intellectual Property Organization, Traditional KnowledgeOperational Terms and Definitions, WIPO Doc WIPO/GRTKF/IC/3/9 (20 May 2002).

36 United Nations Educational Scientific and Cultural Organization (UNESCO) and World Intellectual Property Organization, Model Provisions for National Laws on the Protection of Expressions of Folklore Against Illicit Exploitation and Other Prejudicial Actions (1985) ('UNESCO Model Folklore Provisions').

$37 C B D$ art $8(\mathrm{j})$.

38 Marie Battiste and James [Sa'ke'j] Youngblood Henderson, Protecting Indigenous Knowledge and Heritage: A Global Challenge (Purich Publishing Ltd, 2000); Susette Biber-Klemm and Danuta Szymura Berglas, above n 2, 3; Darrell A. Posey, 'Biological and Cultural Diversity' in Luisa Maffi (ed), On Biocultural Diversity: Linking Language, Knowledge and the Environment (Smithsonian Institution Press, 2001).

39 Terri Janke, Our Culture, Our Future: A Report on Australian Indigenous Cultural and Intellectual Property Rights (Michael Frankel and Company, 1999).

40 World Intellectual Property Organization, Intellectual Property Needs and Expectations of Traditional Knowledge Holders: WIPO Report on Fact-Finding Missions on Intellectual Property and Traditional Knowledge 1998-1999 (April 2001).

${ }_{41}$ Marie Battiste and James [Sa'ke'j] Youngblood Henderson, above n 38, 36-7.

42 Michael Dodson and Olivia Barr, above n 24. 
tices of indigenous and local communities embodying traditional lifestyles' ${ }^{43}$ collectively owned and orally passed down from generation to generation. ${ }^{44}$ In this context, traditional knowledge is viewed as having practical application in the 'fields of agriculture, fisheries, health, horticulture and forestry' ${ }^{45}$ The Nagoya Protocol builds upon the approach set out in the CBD by establishing a framework for the protection of genetic resources and traditional knowledge associated with genetic resources that is held by Indigenous and local communities. $^{46}$

From an intellectual property perspective, the World Intellectual Property Organization ('WIPO') has made several attempts to reach agreement on the definition of traditional knowledge. Historically, WIPO has used the term 'traditional knowledge' to encompass almost all forms of western intellectual property, including 'tradition-based literary, artistic or scientific works; performances; inventions; scientific discoveries; designs; marks; names and symbols; undisclosed information; and all other tradition-based innovations and creations resulting from intellectual activity in the industrial, scientific, literary or artistic fields. ${ }^{97}$ More recently, WIPO has attempted to distinguish between 'traditional knowledge' and 'traditional cultural expressions'. ${ }^{48}$ This approach divides the broader concept of 'traditional knowledge' into two related terms that closely align with the western system of intellectual property rights, particularly copyright and patents. The WIPO Intergovernmental Committee on Intellectual Property and Genetic Resources, Traditional Knowledge and Folklore ('WIPO IGC') defines traditional knowledge as including the 'knowledge, know-how, skills and practices that are developed, sustained and passed on from generation to generation within a community, often forming part of its cultural or spiritual identity'. ${ }^{49}$ This can be contrasted

\footnotetext{
$43 \quad C B D$ art $8(\mathrm{j})$.

44 Convention on Biological Diversity, Background Material, Traditional
} Knowledge Information Portal, accessed 3 November 2019 at https://www.cbd.int/tk/ material.shtml.

45 Ibid.

46 See, e.g., Nagoya Protocol art 7.

47 World Intellectual Property Organization, Intellectual Property Needs and Expectations of Traditional Knowledge Holders: WIPO Report on Fact-Finding Missions on Intellectual Property and Traditional Knowledge 1998-1999 (April 2001) 25.

48 World Intellectual Property Organization, The Protection of Traditional Knowledge: Draft Articles Rev. 2 (22 March 2019), WIPO Doc WIPO/GRTKF/ IC/40/4 (9 April 2019); World Intellectual Property Organization, The Protection of Traditional Cultural Expressions: Draft Articles Rev. 2 (22 March 2019), WIPO Doc WIPO/GRTKF/IC/40/5 (9 April 2019).

49 World Intellectual Property Organization, Traditional Knowledge, accessed 1 November 2019 at https://www.wipo.int/tk/en/tk. 
with the WIPO IGC definition of 'traditional cultural expressions', which includes artistic, literary and cultural expressions such as music, dance, art, performances and ceremonies. ${ }^{50}$

Based on this division of terms, some progress has been made at the WIPO IGC on reaching agreement on a legal framework for the protection of traditional knowledge and the protection of traditional cultural expressions. ${ }^{51}$ The drafting process has been carried out with the participation of member countries, Indigenous representatives and other stakeholders. However, this approach has not been without controversy. ${ }^{52}$ The distinction made by WIPO between traditional knowledge and traditional cultural expressions has been criticised for attempting to force Indigenous knowledge into the framework provided by the western intellectual property system. ${ }^{53}$ In so doing, this approach fails to recognise the holistic and interconnected nature of traditional knowledge and the fact that traditional knowledge as defined by WIPO is often expressed in or by traditional cultural expressions (for example, the use of songs or artwork to communicate knowledge). ${ }^{54}$

Despite the diversity of terms used both in international law and in the literature, ${ }^{55}$ it is possible to distil several common key features. Traditional knowledge encompasses three dimensions: cultural, temporal and spatial. ${ }^{56}$

50 World Intellectual Property Organization, Traditional Cultural Expressions, accessed 1 November 2019 at https://www.wipo.int/tk/en/folklore.

${ }^{51}$ Patricia Adjei and Natalie Stoianoff, 'The World Intellectual Property Organization (WIPO) and the Intergovernmental Committee: Developments on Traditional Knowledge and Cultural Expressions' (2013) 92 Intellectual Property Forum 37, 38.

52 Ibid.

53 Ibid.

54 See, e.g., the artwork on the cover page of the report 'Our Culture, Our Future' by Terri Janke and the description of the meaning behind the artwork set out on the inner cover page. Terri Janke, above n 39, 'Cover and Inner Cover'.

55 Despite many attempts to define traditional knowledge there is no universally accepted definition with different terminology used depending on the context. For example, traditional knowledge has variously been described as 'expressions of folklore', 'traditional knowledge, innovations and practices', 'traditional ecological knowledge', 'indigenous cultural and intellectual property' and more simply 'traditional knowledge'. See, e.g., World Intellectual Property Organization, Traditional Knowledge-Operational Terms and Definitions, WIPO Doc WIPO/GRTKF/IC/3/9 (20 May 2002); UNESCO Model Folklore Provisions; CBD art 8(j); Marie Battiste and James [Sa'ke'j] Youngblood Henderson, above n 38, 46; Darrel A. Posey, above n 38; World Intellectual Property Organization, Intellectual Property Needs and Expectations of Traditional Knowledge Holders: WIPO Report on Fact-Finding Missions on Intellectual Property and Traditional Knowledge 1998-1999 (April 2001).

56 Secretariat, Convention on Biological Diversity, Development of Elements of Sui Generis Systems for the Protection of Traditional Knowledge, Innovations and 
First, traditional knowledge reflects the culture and values of a community ${ }^{57}$ and use of the word 'traditional' reflects the fact that the creation and use of such knowledge is linked to the traditions, cosmology, customs and customary law of an Indigenous or local community. ${ }^{58}$ Second, traditional knowledge is passed down through generations ${ }^{59}$ and, rather than remaining ancient or static, is dynamic and continually evolving. ${ }^{60}$ Finally, traditional knowledge is place-based, arising from the land, and is the achievement of a specific Indigenous or local community. ${ }^{61}$

While recognising the importance of traditional cultural expressions, and the issues associated with dealing with 'traditional knowledge' as distinct or separate from 'traditional cultural expressions', for the purpose of engaging in a detailed analysis this book will address the protection of traditional knowledge as defined by WIPO; that is, the know-how, skills, innovations, practices and teachings and learnings of Indigenous people and local communities. ${ }^{62}$ This choice is made to reflect the approach of both the Nagoya Protocol and the WIPO IGC and will provide the framework for the comparative analysis undertaken in Chapters 2 to 5.

Practices to Identify Priority Elements, Doc No UNEP/CBD/WG8J/5/6 (20 September 2007) 16.

57 Michael Dodson and Olivia Barr, above n 24, 20; Charles McManis and Yolanda Teran, above n 5, 140.

58 Marie Battiste and James [Sa'ke'j] Youngblood Henderson, above n 38, 46; World Intellectual Property Organization, Intellectual Property Needs and Expectations of Traditional Knowledge Holders: WIPO Report on Fact-Finding Missions on Intellectual Property and Traditional Knowledge 1998-1999 (April 2001) 212; Peter Drahos, 'When cosmology meets property: indigenous peoples' innovation and intellectual property' (2011) 29(3) Prometheus 233, 242.

59 Michael Dodson and Olivia Barr, above n 24, 20.

60 Douglas Nakashima, 'Conceptualising Nature: The Cultural Context of Resource Management' (1998) 34 Nature Resources UNESCO 8, 18; Madhavi Sunder, 'The Invention of Traditional Knowledge' (Spring 2007) 70 Law and Contemporary Problems 97, 100; Graham Dutfield, above n 7, ix; Darrell A. Posey, above n 38, 382.

${ }_{61}$ Peter Drahos and Susy Frankel, 'Indigenous Peoples' Innovation and Intellectual Property: The Issues' in Peter Drahos and Susy Frankel, Indigenous Peoples' Innovation: Intellectual Property Pathways to Development (ANU E Press, 2012) 1, 13; Susette Biber-Klemm and Danuta Szymura Berglas, above n 2, 19; Peter Drahos, above $\mathrm{n} 58$.

${ }_{62}$ World Intellectual Property Organization, The Protection of Traditional Knowledge: Draft Articles Rev. 2 (22 March 2019), WIPO Doc WIPO/GRTKF/ IC/40/4 (9 April 2019); World Intellectual Property Organization, The Protection of Traditional Cultural Expressions: Draft Articles Rev. 2 (22 March 2019), WIPO Doc WIPO/GRTKF/IC/40/5 (9 April 2019). 


\section{Indigenous and Local Peoples}

Traditional knowledge is place-based and attributed to a specific Indigenous or local community. Indigenous and local peoples are the holders and custodians of traditional knowledge. As observed by Erica-Irene Daes in her 1996 report to the Working Group on Indigenous Populations, best practice is to provide opportunities and support Indigenous and local communities to exercise sovereignty and engage in the practice of self-identification. ${ }^{63}$ The International Labour Organization ('ILO') Convention on Indigenous and Tribal Peoples in Independent Countries ${ }^{64}$ and the United Nations Declaration on the Rights of Indigenous Peoples ${ }^{65}$ explicitly support this approach.

While there is no settled definition of 'Indigenous peoples', Daes identifies four factors that are common to Indigenous communities. First, Indigenous and local communities are the first to occupy and use a specific defined territory ${ }^{66}$ The Indigenous or local community can demonstrate some form of historical continuity or pre-colonial connection with the land (even though such connection may have been disrupted as a result of colonisation) ${ }^{67}$ Second, Indigenous and local communities engage in 'voluntary perpetuation' of distinct cultural attributes, such as language, social structure, values, laws and institutions. ${ }^{68}$ Third, membership of Indigenous and local communities is determined through a process of self-identification, as well as recognition by third parties or governments as a distinct population. ${ }^{69}$ Finally, Indigenous and local com-

63 Erica-Irene A. Daes, Working Paper by the Chair Person-Rapporteur Mrs Erica-Irene A. Daes on the concept of 'indigenous people' UN Doc E/CN.4/Sub.2/ AC.4/1996/2 (10 June 1996) 21.

64 Convention (No 169) Concerning Indigenous and Tribal Peoples in Independent Countries, opened for signature 27 June 1989, 1650 UNTS 383 (entered into force 5 September 1991) art 1(2): 'Self-identification as indigenous or tribal shall be regarded as a fundamental criterion for determining the groups to which the provisions of this Convention apply'.

65 United Nations Declaration on the Rights of Indigenous Peoples, GA Res 61/295, UN GAOR, 61st sess, Supp No 49, UN Doc A/RES/61/295 (2 October 2007) ('UNDRIP') art 33.1: 'Indigenous peoples have the right to determine their own identity or membership in accordance with their customs and traditions. This does not impair the right of indigenous individuals to obtain citizenship of the States in which they live'.

${ }_{66}$ Erica-Irene A. Daes, above n 63, 22 [69].

67 World Council of Indigenous Peoples, Presumed dead . . but still useful as a human by-product (1993) cited in Darrell A. Posey, 'Protecting Indigenous Peoples' Rights to Bio Diversity: People, Property and Bioprospecting' (1996) 38(8) Environment 6, 8 .

68 Erica-Irene A. Daes, above n 63, 22 [69].

69 Ibid. 
munities have been subject to historical, and often continuing, experiences of 'subjugation, marginalization, dispossession, exclusion or discrimination' ${ }^{70}$

The phrase 'Indigenous and local communities' is used in the $\mathrm{CBD},{ }^{71}$ the Nagoya Protocol ${ }^{72}$ and by WIPO. ${ }^{73}$ The term is used in the CBD in the context of those Indigenous and local communities who 'embody traditional lifestyles relevant for the conservation and sustainable use of biological diversity' ${ }^{74}$ The WIPO Draft Articles, however, reflect the tensions and difficulties in reaching consensus on a suitable definition. The latest version of the Draft Articles (released in April 2019) contains a number of bracketed terms that are still the subject of negotiation with reference made to 'indigenous [peoples] and local communities'. ${ }^{75}$

While the phrase 'Indigenous and local community' is commonly used to represent knowledge and rights holders in the context of protecting traditional knowledge, other terms such as 'aboriginal', 'local community' or 'tribal community' are also used. The diversity of terms reflects the diversity of Indigenous communities globally. The term 'Indigenous' is often viewed as referring to peoples in enclave colonies where settlers (or invaders) have failed to withdraw such as Australia, New Zealand, Canada and the United States of America. ${ }^{76}$ The purpose of adding 'local community' to 'Indigenous' is to recognise that in some countries it would be inappropriate to use the term 'Indigenous', as much of the population could be classified as such. For example, in countries that have not been subject to colonisation, or in those countries that have transitioned, or are transitioning, to a post-colonial context, it may be more appropriate to refer to specific tribal or local communities. This broader definition of 'Indigenous and local peoples' is important as a limited conception of 'indigenous peoples . . . tends to exclude most other colonised peoples and territories where settler withdrawal ushered in political independence and a form of decolonisation. ${ }^{77}$

\footnotetext{
70 Ibid.

${ }^{71} C B D$ art 8(j).

72 Nagoya Protocol art 7.

73 World Intellectual Property Organization, The Protection of Traditional Knowledge: Draft Articles Rev. 2 (March 22, 2019), WIPO Doc WIPO/GRTKF/ IC/40/4 (9 April 2019).

$74 C B D$ art $8(\mathrm{j})$.

75 See, e.g., World Intellectual Property Organization, The Protection of Traditional Knowledge: Draft Articles Rev. 2 (22 March 2019), WIPO Doc WIPO/GRTKF/IC/40/4 (9 April 2019) Preamble.

76 Chidi Oguamanam, 'Protecting indigenous knowledge in international law: solidarity beyond the nation state' (2004) 8(1) Law Text Culture 191, 198.

77 Ibid.
} 
There are inherent dangers in seeking to define what is meant by the term 'Indigenous and local community'. Indigenous communities are not homogeneous at an international, regional or national level ${ }^{78}$ and, in many cases, the community identity that is required by some of the proposed definitions has been destroyed by invasion or colonisation. ${ }^{79}$ The ability to satisfy criteria related to descent or connection to a particular geographical location has been forever impacted by policies of dispossession, assimilation and so-called 'protection'. ${ }^{80}$

However, as with the approach taken to the definition of traditional knowledge, it is important to focus the frame of inquiry. As such, the terms 'Indigenous and local people(s)' and 'Indigenous and local community(ies)' will be used to refer to holders of traditional knowledge and the potential beneficiaries under any regime for the protection of traditional knowledge generally. References to 'Indigenous and local peoples or communities' should be interpreted using the criteria set out by Daes as discussed above. Other terms may be used where necessary to reflect language used in specific legislation.

\section{WHY PROTECT TRADITIONAL KNOWLEDGE?}

Reflecting the value of traditional knowledge, there are many cases where such knowledge has been appropriated and exploited through practices often labelled 'biopiracy' ${ }^{81}$ While use of the term 'biopiracy' is contested, the term is used in this book as it is deployed in characterisations of the exploitation and misappropriation of traditional knowledge at international, national and

78 Jane Anderson, 'The Politics of Indigenous Knowledge: Australia's Proposed Communal Moral Rights Bill' (2004) 27(3) University of New South Wales Law Journal 585, 587; Erica-Irene A. Daes, above n 63, 5 [9].

79 Jane Anderson, above n 78, 591.

80 See, e.g., in Australia, Aborigines Protection Act 1909 (NSW); Child Welfare Act 1939 (NSW); Children (Care and Protection) Act 1987 (NSW); The Policy of Assimilation: Decisions of Commonwealth and State Ministers at the Native Welfare Conference, Canberra, 26-27 January 1961, accessed 2 November at https://aiatsis.gov .au/sites/default/files/catalogue_resources/18801.pdf.

${ }^{81}$ See, e.g., Daniel F. Robinson, 'Traditional Knowledge and Biological Product Derivative Patents: Benefit-Sharing and Patent Issues Relating to Camu Camu, Kakadu Plum and Acai Plant Extracts' (April 2010) Traditional Knowledge Bulletin: Topical Issues Series; Stephen Gray, 'Vampires round the campfire' (1997) 22(2) Alternative Law Journal 60; Oliver Krackhardt, 'Beyond the Neem Tree Conflict: Questions of Corporate Behaviour in a Globalised World' (June 2005) 21 New Zealand Universities Law Review 347; Margo A. Bagley, 'Patently Unconstitutional: The Geographical Limitation on Prior Art in a Small World' (2003) 87 Minnesota Law Review 679; Amanda J. Landon, 'Bioprospecting and Biopiracy in Latin America: The Case of Maca in Peru' (2007) 22 Nebraska Anthropologist 63. 
academic forums. Early use of the term 'biopiracy' is attributed to the Rural Advancement Foundation International ('RAFI') (now known as the 'ETC Group') and refers to the practice of:

appropriation of the knowledge and genetic resources of farming and indigenous communities by individuals or institutions who seek exclusive monopoly control (patents or intellectual property) over these resources or knowledge. ${ }^{82}$

Dutfield observes that biopiracy involves 'one or both of the following acts: (i) the misappropriation of genetic resources and/or traditional knowledge through the patent system; and (ii) the unauthorised collection for commercial ends of genetic resources and/or traditional knowledge' ${ }^{83}$ Robinson divides the concept of biopiracy into three categories: (i) patent-based biopiracy-the patenting of inventions based on the use of traditional knowledge obtained without prior informed consent or benefit sharing; (ii) non-patent based biopiracy - the grant of other forms of intellectual property protection, such as plant breeder's rights or trademarks, based on the use of traditional knowledge obtained without prior informed consent or benefit sharing; and (iii) misappropriation in the form of use of traditional knowledge without prior informed consent or adequate benefit sharing. ${ }^{84}$ Indigenous and local communities around the world experience acts of biopiracy, with numerous examples documented worldwide including the misappropriation and exploitation of maca root and ayahuasca vine in Peru and the neem tree and turmeric in India (see Chapter 2 for further discussion of these examples).

Despite the vocal opposition of Indigenous and local communities and their supporters to acts of biopiracy, there are commentators who argue that traditional knowledge should not receive any special protection and who believe that Indigenous innovation is sufficiently protected as a form of intellectual property under the western system of intellectual property law. ${ }^{85}$ Chen argues that ' $[\mathrm{m}]$ ost allegations of biopiracy are so thoroughly riddled with inconsistencies and outright lies that the entire genre, pending further clarification, must be consigned to the realm of "rural" legend'. ${ }^{86}$ In this context, traditional knowledge is viewed as the heritage of mankind and, therefore, a resource that

82 ETC Group, Patents \& Biopiracy, accessed 30 October 2019 at http://www .etcgroup.org/issues/patents-biopiracy.

83 Graham Dutfield, above n 7, 6.

84 Daniel Robinson, Confronting Biopiracy: Challenges, Cases and International Debates (Earthscan, 2010) 21.

85 Jim Chen, 'There's No Such Thing as Biopiracy . . . and It's a Good Thing Too' (2006) 37 McGeorge Law Review 1, 22.

86 Ibid 5. 
should remain in the common or public domain. ${ }^{87}$ Chen argues that it is not economically justifiable to support a system that would remove knowledge from the public domain and assign it to a private owner or owners. ${ }^{88}$ Oxley also contests the existence of biopiracy. Referencing research conducted by the Australian APEC Centre, Oxley states there are 'no instances of the forcible, illegal removal of genetic resources in any jurisdiction' ${ }^{89}$ Accordingly, Oxley views any attempt to protect traditional knowledge from exploitation as imposing burdensome regulation that would result in reduced investment and unnecessarily impede industry. ${ }^{90}$ These arguments are based on the flawed assumption that traditional knowledge is in the public domain, the intellectual equivalent of terra nullius. ${ }^{91}$ As discussed above, traditional knowledge is linked to the traditions, customary law and cosmology of a particular Indigenous or local community; it is place-based and the achievement of a specific Indigenous or local community. ${ }^{92}$

There is also opposition to the use of the term 'biopiracy'. Heald observes that the traditional justifications for protection of traditional knowledge as a form of intellectual property are not available to Indigenous and local communities. He argues that the rhetoric of biopiracy, based on the theories of moral obligation and unjust enrichment, does a disservice to Indigenous and local communities. ${ }^{93}$ Heald suggests that Indigenous communities should engage with multi-national corporations on a pragmatic basis that is 'less

\section{Ibid 24.}

88 Ibid 22.

89 Alan Oxley, Tim Wilson and Sophie Edelstein, Retarding Development: Compulsory disclosure in IP law of ownership and use of biological or genetic resources (The Australian APEC Study Centre, Monash University, 2005) 13, citing Bill Bowen, Developing an effective regime for access and benefit sharing for genetic resources using market-based instruments (The Australian APEC Study Centre, Monash University, 2005).

90 Alan Oxley, Tim Wilson and Sophie Edelstein, above n 89, 4.

91 Terra nullius means 'nobody's land' and was used to justify the invasion and subsequent settlement of Australia by the British despite over 60,000 years of continued occupation by Aboriginal and Torres Strait Islander peoples. See Mabo v State of Queensland (No 2) [1992] HCA 23, [33]-[46] for further detail on the policy and application of 'terra nullius'.

92 Michael Dodson and Olivia Barr, above n 24, 20; Charles McManis and Yolanda Teran, above n 5, 140; Marie Battiste and James [Sa'ke'j] Youngblood Henderson, above n 38, 46; World Intellectual Property Organization, Intellectual Property Needs and Expectations of Traditional Knowledge Holders: WIPO Report on Fact-Finding Missions on Intellectual Property and Traditional Knowledge 1998-1999 (April 2001), 212; Peter Drahos, above n 58; Peter Drahos and Susy Frankel, above n 61; Susette Biber-Klemm and Danuta Szymura Berglas, above n 2, 19.

93 Paul J. Heald, 'The Rhetoric of Biopiracy' (2003-2004) 11 Cardozo Journal of International and Comparative Law 519, 520. 
threatening to their interests and more likely to achieve concrete results' ${ }^{94}$ While this may be 'less threatening', it assumes that there is no power imbalance between the respective parties and that the corporate interests are prepared to engage on a level playing field. This argument also undermines Indigenous rights to self-determination by limiting the choices of Indigenous and local peoples as to how they may engage with third parties and make decisions relating to their traditional knowledge. Another perspective on the issue uses human rights theory to argue that special rights in traditional knowledge would limit access to vital aspects of the public domain and threaten basic human rights such as freedom of speech and the freedom to share information or exchange ideas. ${ }^{95}$ However, other systems of intellectual property rights have been readily introduced to address other special interests, including rights in semiconductors or plant variety rights without any disproportionate impact on basic human rights. ${ }^{96}$

There are three main aspects to the argument for protecting traditional knowledge against acts of biopiracy. First, there are strong ideological grounds for the protection of traditional knowledge. The practice of biopiracy is offensive to many Indigenous people and represents the continuing dispossession of communities that have suffered both historical and contemporary wrongs. ${ }^{97} \mathrm{As}$ discussed by Laurelyn Whitt, such acts represent a process of bio-colonialism, whereby traditional knowledge is appropriated and exploited by a dominant culture resulting in, inter alia, damage to the environment, negative consequences for Indigenous health, destabilisation of Indigenous institutions and disruption of traditional knowledge systems.$^{98}$ This arises from 'the ideology, the policies, and the practices of a new imperial science, marked by the confluence of science with capitalism - a relationship mediated by a distinctively American, increasingly international, intellectual property system'. ${ }^{99}$ This process is yet another wrong perpetrated against Indigenous and local

$94 \quad$ Ibid 543.

95 Jim Chen, above n 85, 23; Michael Brown, 'Can Culture Be Copyrighted?' (1998) 39 Current Anthropology 193 cited in Rosemary Coombe, 'Intellectual Property, Human Rights and Sovereignty: New Dilemmas in International Law posed by the Recognition of Indigenous Knowledge and the Conservation of Biodiversity' (1998) 6 Indiana Journal of Global Legal Studies 59, 78.

96 Peter Drahos, 'Indigenous Knowledge and the Duties of Intellectual Property Owners' (1997) 11 Intellectual Property Journal 179, 194.

97 UTS-Indigenous Knowledge Forum and North West Local Land Services, 'Recognising and Protecting Aboriginal Knowledge Associated with Natural Resource Management' (White Paper, Office of Environment and Heritage, Government of New South Wales, 2014) 3.

98 Laurelyn Whitt, above n 8, 23-4.

99 Ibid xiv. 
communities, contributing to the suppression of institutions that positively affirm Indigenous values, cultures and identities ${ }^{100}$ and potentially preventing Indigenous people from engaging in industries based on their traditional knowledge. ${ }^{101}$ Working within a framework of corrective justice, rights in traditional knowledge may be used, among other tools, to return to Indigenous and local communities institutions that affirm and support Indigenous values and practices. ${ }^{102}$

Second, acts of biopiracy threaten to undermine the integrity of the patent system. The patent system requires that, to obtain a monopoly in the form of patent rights, the alleged invention must be novel and involve an inventive step when compared to the prior art base. The prior art base includes information that is made publicly available, either through publication or public acts. The integrity of the patent system is predicated upon the principle that monopoly rights may only be granted for new inventions. This integrity is undermined when patents are granted over inventions that involve traditional knowledge and do not meet the requirements of novelty or inventive step when compared to the prior art base, particularly in light of prior use of the traditional knowledge by the knowledge holders.

Third, protecting traditional knowledge from acts of biopiracy may result in economic benefits for Indigenous and local communities. As discussed above, traditional knowledge is not simply 'old' or 'ancient' knowledge; it is dynamic, continually adapting and evolving to respond to new environments or circumstances. ${ }^{103}$ Furthermore, not all traditional knowledge is in the public domain and therefore available to all. This knowledge and resulting innovation is worthy of protection, even if it does not meet the criteria for protection under western intellectual property law due to the way it is created and maintained. Providing such protection allows Indigenous and local communities to determine and appropriate the value of their traditional knowledge and, therefore, to determine the direction of wealth transfer and engage in industry based on their

100 Douglas Sanderson, above n 26.

101 Henrietta Fourmile-Marrie, above n 14, 164; Katie O'Bryan, above n 15; Vandana Shiva, above n 14, 14.

102 Douglas Sanderson, above n 26.

103 Natalie Stoianoff, 'Navigating the Landscape of Indigenous Knowledge - A Legal Perspective' (2012) 90 Intellectual Property Forum 23, 24-5; Antony Taubman and Matthias Leistner, 'Traditional Knowledge' in Silke von Lewinski (ed), Indigenous Heritage and Intellectual Property: Genetic Resources, Traditional Knowledge and Folklore (Wolters Kluwer, 2nd ed, 2008) 59, 61; Sonia Smallcombe, Michael Davis and Robynne Quiggan, Scoping Project on Aboriginal Traditional Knowledge: Report of a Study for the Desert Knowledge Cooperative Research Centre (Desert Knowledge Cooperative Research Centre, 2006) 7-8. 
knowledge. ${ }^{104}$ Protecting traditional knowledge also facilitates compliance with international obligations under a diverse range of treaties, declarations and agreements.

\section{TRADITIONAL KNOWLEDGE AND INTERNATIONAL LAW}

There has been increasing recognition at an international level of the need to protect traditional knowledge, and several treaties and declarations have been enacted that afford some measure of protection for traditional knowledge. The most important international agreements for the purposes of this book are the CBD, the Nagoya Protocol, the International Treaty on Plant Genetic Resources for Food and Agriculture ('ITPGRFA') ${ }^{105}$ and the United Nations Declaration on the Rights of Indigenous Peoples ('UNDRIP'). ${ }^{106}$

The CBD entered into force in 1993 with the objective of promoting the conservation and sustainable use of biological diversity and the fair and equitable sharing of the benefits arising out of the utilisation of genetic resources. ${ }^{107}$ The CBD operates on the principle that states have "the sovereign right to exploit their own resources pursuant to their own environmental policies, and the responsibility to ensure that activities within their jurisdiction or control do not cause damage to the environment of other States or of areas beyond the limits of national jurisdiction. ${ }^{108}$ Central to the CBD is the recognition of the role Indigenous and local communities play with respect to the sustainable use and development of biological resources and associated traditional knowledge, and the importance of 'sharing equitably benefits arising from the use of traditional knowledge, innovations and practices relevant to the conservation of biological diversity and sustainable use of its components' ${ }^{109}$ Parties to the $\mathrm{CBD}$ are required to endeavour to establish access and benefit-sharing arrangements based on prior informed consent and mutually agreed terms. ${ }^{110}$

\footnotetext{
104 Peter Drahos, above n 96, 196.

105 International Treaty on Plant Genetic Resources for Food and Agriculture, opened for signature 3 November 2001, 2400 UNTS 43345 (entered into force 29 June 2004) ('ITPGRFA').

106 UN Declaration on the Rights of Indigenous Peoples, GA Res 61/295, UN GAOR, 61 st sess, Supp No 49, UN Doc A/RES/61/295 (2 October 2007) ('UNDRIP').

$107 C B D$ art 1.

108 Ibid art 3.

109 Ibid Preamble.

110 Ibid art 15.
} 
Specific provisions deal with the protection of traditional knowledge; contracting parties must:

[s]ubject to national legislation, respect, preserve and maintain knowledge, innovations and practices of indigenous and local communities embodying traditional lifestyles relevant for the conservation and sustainable use of biological diversity and promote their wider application with the approval and involvement of the holders of such knowledge, innovations and practices and encourage the equitable sharing of the benefits arising from the utilization of such knowledge, innovations and practices. ${ }^{111}$

As observed by Schroder and Pisupati, there are clear links between the objectives of the CBD and the theory of justice, in particular distributive justice and justice in exchange. ${ }^{12}$ The rationale underlying the $\mathrm{CBD}$ is that fair and equitable benefit sharing is required in order to secure the conservation and sustainable use of genetic resources. Benefit sharing is therefore framed as compensation for access as opposed to a charitable contribution to Indigenous and local communities. ${ }^{113}$ Reflecting this approach, the Conference of the Parties to the CBD endorses the use of "sui generis models for the protection of traditional knowledge, innovations and practices with the full and effective participation of indigenous and local communities'. ${ }^{114}$ In 1998 the Conference of the Parties to the CBD established the Ad Hoc Open-ended Working Group on Article 8(j) and Related Provisions of the Convention on Biological Diversity to support implementation of the provisions related to the protection of traditional knowledge. ${ }^{115}$ The Working Group has recently prepared voluntary guidelines providing guidance to member countries in the development of legislation or other measures to protect traditional knowledge based on the

111 Ibid art 8(j).

112 Doris Schroeder and Balakrishna Pisupati, Ethics, Justice and the Convention on Biological Diversity (UNEP, 2010) 21. See also, Bram De Jonge, 'What is Fair and Equitable Benefit-sharing' (2011) 24 Journal of Agricultural and Environmental Ethics 127; Elisa Morgera, 'The Need for an International Legal Concept of Fair and Equitable Benefit Sharing' (2016) 27(2) European Journal of International Law 353; Saskia Vermeylen, 'Conceptualising "Fair" and "Equitable": The San's Reflections on the Hoodia Benefit-Sharing Agreement' (2007) 12(4) Local Environment 423.

113 Doris Schroeder, 'Benefit sharing: it's time for a definition' (2006) 33(4) Journal of Medical Ethics 205, 207.

114 Conference of the Parties to the Convention on Biological Diversity, Decision VIII/5: Article 8(j) and related provisions, Doc No UNEP/CBD/COP/DEC/VIII/5 (15 June 2006) 16, accessed 1 November 2019 at https://www.cbd.int/doc/decisions/cop -08/cop-08-dec-05-en.pdf.

115 Convention on Biological Diversity, Working Group on Article 8(j), accessed 1 November 2019 at https://www.cbd.int/convention/wg8j.shtml. 
principles of prior informed consent and fair and equitable benefit sharing. ${ }^{116}$ These guidelines were adopted at the 13th meeting of the Conference of the Parties to the Convention on Biological Diversity in December 2016. ${ }^{117}$

The Nagoya Protocol, which entered into force in October 2014, implements the access and benefit-sharing obligations arising out of the CBD. The Protocol specifically addresses access to traditional knowledge associated with genetic resources, with each contracting party required to:

take measures, as appropriate, with the aim of ensuring traditional knowledge associated with genetic resources that is held by indigenous and local communities is accessed with the prior and informed consent or approval and involvement of these indigenous and local communities, and that mutually agreed terms have been established. ${ }^{118}$

The Protocol also requires contracting parties to establish mechanisms to ensure that traditional knowledge associated with genetic resources has been accessed with prior informed consent (or approval and involvement) of the relevant Indigenous or local community and upon mutually agreed terms. ${ }^{119}$ Such measures may be administrative, legislative or policy-based and are to be implemented taking into account the customary laws, community protocols and procedures of the relevant Indigenous or local community. ${ }^{120}$ Contracting parties are obliged to support, as appropriate, the development of community protocols in relation to access and benefit sharing, minimum requirements and model contractual clauses for mutually agreed terms to assist in securing the fair and equitable sharing of benefits arising from the utilisation of traditional

116 Ad hoc Open-Ended Inter-Sessional Working Group on Article 8(j) and Related Provisions of the Convention on Biological Diversity, Recommendation Adopted by the Working Group: Voluntary Guidelines for the development of mechanisms, legislation or other appropriate initiatives to ensure the [free,] prior informed consent [or approval and involvement] of indigenous peoples and local communities for accessing their knowledge, innovations and practices, the fair and equitable sharing of benefits arising from the use and application of such knowledge, innovations and practices relevant for the conservation and sustainable use of biological diversity and for reporting and preventing unlawful appropriation of traditional knowledge, Doc No UNEP/CBD/ WG8J/REC/9/1 (7 November 2015), accessed 1 November 2019 at https://www.cbd .int/doc/recommendations/wg8j-09/wg8j-09-rec-01-en.pdf.

117 Conference of the Parties to the Convention on Biological Diversity, Decision Adopted by the Conference of the Parties to the Convention on Biological Diversity XIII/18 Article 8(j) and related provisions 'Mo'otz Kuxtal Voluntary Guidelines', Doc No CBD/COP/DEC/XIII/18 (17 December 2016), accessed 1 November 2019 at https://www.cbd.int/doc/decisions/cop-13/cop-13-dec-18-en.pdf.

118 Nagoya Protocol art 7.

119 Ibid art 16.

120 Ibid art 12.1. 
knowledge associated with genetic resources. ${ }^{121}$ While the CBD and Nagoya Protocol have been criticised for their emphasis on state sovereignty over resources, ${ }^{122}$ they are important sources of some form of protection for traditional knowledge.

While the CBD and Nagoya Protocol focus on the broad issues of sustainable use and conservation of biological diversity generally, the ITPGRFA is targeted at the 'conservation and sustainable use of plant genetic resources for food and agriculture'. ${ }^{123}$ Linking to the CBD, ${ }^{124}$ the ITPGRFA recognises the 'enormous contribution that the local and indigenous communities and farmers of all regions of the world' have made with regards to conservation and development of plant genetic resources. ${ }^{125}$ The ITPGRFA sets out 'Farmers' Rights' and requires contracting parties to, subject to national legislation, take measures to protect traditional knowledge relevant to plant genetic resources for food and agriculture ${ }^{126}$ and to protect the rights of farmers to participate in equitable sharing of benefits arising from the utilisation of plant genetic resources for food and agriculture. ${ }^{127}$

In addition to the treaties focused on conservation and sustainable use described above, the United Nations Declaration on the Rights of Indigenous Peoples has addressed the protection of traditional knowledge from a human rights perspective. UNDRIP was adopted by the UN General Assembly in 2007 and contains comprehensive provisions relating to traditional knowledge. Article 31(1) recognises the rights of Indigenous peoples to:

maintain, control, protect and develop their cultural heritage, traditional knowledge and traditional cultural expressions, as well as the manifestations of their sciences, technologies and cultures, including human and genetic resources, seeds, medicines, knowledge of the properties of fauna and flora, oral traditions, literatures, designs, sports and traditional games and visual and performing arts. They also have the right to maintain, control, protect and develop their intellectual property over such cultural heritage, traditional knowledge, and traditional cultural expressions. ${ }^{128}$

The Declaration requires states to work with Indigenous peoples to take effective measures to recognise and protect these rights. ${ }^{129}$ While the Declaration is

\footnotetext{
121 Ibid art 12.3.

122 See, e.g., Peter Drahos, Intellectual Property, Indigenous People and their Knowledge (Cambridge University Press, 2014) 76-8.

123 ITPGRFA art 1.1.

124 Ibid art 1.2.

125 Ibid art 9.1 .

126 Ibid art 9.2(a).

127 Ibid art 9.2(b).

128 UNDRIP art 31(1).

129 Ibid art 31(2).
} 
non-binding, it represents increasing recognition by the international community of the rights of Indigenous people and the development of an environment conducive to greater protection of such rights. ${ }^{130}$

In addition to the international agreements set out above, the WIPO has been active in this area. The WIPO IGC $^{131}$ was established in 2000 and it is through this forum that member states have sought to negotiate arrangements for the protection of traditional knowledge, traditional cultural expressions and genetic resources, bringing together the concepts of intellectual property and traditional knowledge within the framework of a benefit-sharing regime. ${ }^{132}$ As discussed briefly above, progress has been made on the negotiation of the Draft Articles for the Protection of Traditional Knowledge, ${ }^{133}$ with recent drafts containing provisions relating to the subject matter of protection, the beneficiaries of protection, scope and term of protection, exceptions and limitations, sanctions and remedies, administration and trans-boundary cooperation. Progress has stalled recently, with the draft agreements containing a number of 'bracketed provisions' still the subject of negotiation. Examples of contentious areas include the use of specific terms and definitions; the scope of protection and criteria for eligibility; and the beneficiaries of such

130 United Nations Human Rights Office of the High Commissioner, 'Adoption of Declaration on Rights of Indigenous Peoples a historic moment for human rights, UN Expert says' (Press Release, 14 September 2007); United Nations Permanent Forum on Indigenous Issues, Declaration on the Rights of Indigenous Peoples: Frequently Asked Questions, accessed 1 November 2019 at https://www.un.org/esa/socdev/unpfii/ documents/faq_drips_en.pdf.

131 It should be noted that while the name WIPO Intergovernmental Committee on Intellectual Property and Genetic Resources, Traditional Knowledge and Folklore makes reference to 'Folklore', WIPO recognises that the use of this term is no longer appropriate in the sense that is does not adequately describe what has come to be referred to as 'traditional cultural expressions'. As such, the Committee is concerned with the protection of intellectual property and genetic resources, traditional knowledge and traditional cultural expressions.

132 Natalie Stoianoff, 'The Recognition of Traditional Knowledge under Australian Biodiscovery Regimes: Why Bother with Intellectual Property Rights?' in Christoph Antons (ed), Traditional Knowledge, Traditional Cultural Expressions and Intellectual Property Law in the Asia-Pacific Region (Kluwer Law International, 2009) 293, 294.

133 World Intellectual Property Organization, The Protection of Traditional Knowledge: Draft Articles Rev. 2 (22 March 2019), WIPO Doc WIPO/GRTKF/ IC/40/4 (9 April 2019); World Intellectual Property Organization, The Protection of Traditional Cultural Expressions: Draft Articles Rev. 2 (22 March 2019), WIPO Doc WIPO/GRTKF/IC/40/5 (9 April 2019); World Intellectual Property Organization, Consolidated Document Relating to Intellectual Property and Genetic Resources Rev. 2 (23 March 2018), WIPO Doc WIPO/GRTKF/IC/40/6 (9 April 2019). 
protection. ${ }^{134}$ The IGC Mandate for 2018-2019 states that the WIPO IGC will 'continue to expedite its work, with the objective of reaching an agreement on an international legal instrument(s), without prejudging the nature of outcome(s), relating to intellectual property which will ensure the balanced and effective protection of genetic resources (GRs), traditional knowledge (TK) and traditional cultural expressions (TCEs)'. ${ }^{135}$

Concurrent with the efforts at an international level, several countries and regional bodies have already established legislative instruments or regimes that provide for the protection of traditional knowledge, including the Andean Community, ${ }^{136}$ Peru, ${ }^{137}$ India, ${ }^{138}$ the Philippines, ${ }^{139}$ Portugal, ${ }^{140}$ Costa Rica ${ }^{141}$ and Brazil. ${ }^{142}$

\section{E. OPTIONS TO PROTECT TRADITIONAL KNOWLEDGE}

As discussed above, there are commentators who argue that traditional knowledge should not receive any special protection. Chen and Oxley question the

134 World Intellectual Property Organization, The Protection of Traditional Knowledge: Draft Articles Rev. 2 (22 March 2019), WIPO Doc WIPO/GRTKF/IC/40/4 (9 April 2019). See also, World Intellectual Property Organization, Indicative List of Outstanding/Pending Issues to be Tackled/Solved (34th Session 12-16 June 2017) WIPO/GRTKF/IC/34/7 (14 March 2017).

135 Assemblies of Member States of WIPO, Matters Concerning the Intergovernmental Committee on Intellectual Property and Genetic Resources, Traditional Knowledge and Folklore, 57th sess, Agenda Item 18, Decision, accessed 2 November 2019 at https://www.wipo.int/export/sites/www/tk/en/igc/pdf/igc_mandate 2018-2019.pdf.

136 Andean Community Decision No 391 Establishing the Common Regime on Access to Genetic Resources, adopted 2 July 1996 (entered into force 17 July 1996) ('Decision 391'); Andean Community Decision No 486 Establishing the Common Industrial Property Regime, adopted 14 September 2000 (entered into force 19 September 2000) ('Decision 486').

137 Law No. 27811 Introducing a Protection Regime for the Collective Knowledge of Indigenous Peoples Derived from Biological Resources 2002 (Peru).

138 Biological Diversity Act 2002 (India); The Scheduled Tribes and Other Traditional Forest Dwellers (Recognition of Forest Rights) Act 2006 (India).

139 Indigenous Peoples Rights Act 1997 (the Philippines).

140 Decree Law No. 118 of 2002 Establishing a Legal Regime of Registration, Conservation, Legal Custody and Transfer of Plant Endogenous Material (Portugal).

${ }^{141}$ Law No. 7788 of 1998 on Biodiversity (Costa Rica).

142 Provisional Measure No. 2186-16 of 2001 Regulating Access to the Genetic Heritage, Protection of and Access to Associated Traditional Knowledge (Brazil); Law No. 13,123 of 20 May 2015 (Access and Benefits Sharing of Genetic Resources and Associated Traditional Knowledge) (Brazil). 
existence of biopiracy and argue that there is no economic justification to support a system that would remove items from the public domain and assign them to a private owner or owners. ${ }^{143}$ The solution, in their view, would be to rely on the existing western intellectual property system, to which, at most, only minor amendments are necessary in order to provide sufficient protection for traditional knowledge. This approach assumes that any instance of traditional knowledge being appropriated or exploited through the grant of unfair patents is the result of an over-reach or incorrect application of existing intellectual property law. ${ }^{144}$ It is, therefore, argued that it is more appropriate to curtail the current system rather than expand intellectual property law to create additional classes of rights. ${ }^{145}$ The primary method proposed to address this 'over-reach' is improved procedures in patent offices to ensure that relevant prior art is searched and assessed prior to a patent being granted. This would include a full assessment of not only prior art published in foreign jurisdictions, but also evidence of prior use or sale. ${ }^{146}$ While improved patent examination procedures may form part of the solution, there are a number of flaws with the use of the western intellectual property system to protect traditional knowledge, as will be addressed in more detail below.

Other amendments to the patent system may also provide further protection for traditional knowledge. Disclosure of origin provisions require that patent applications disclose the source or origin of genetic resources and associated traditional knowledge; evidence of the prior informed consent of the relevant Indigenous or local community; and the existence of mutually agreed terms governing the use of the genetic resources and associated traditional knowledge, including provisions as to the sharing of benefits arising out of such use. ${ }^{147}$ The use of disclosure of origin provisions has been supported by a number of nations through both WIPO and the World Trade Organization. ${ }^{148}$ Opponents to patent disclosure requirements argue that such requirements

143 Jim Chen, above n 85, 22; Alan Oxley, Tim Wilson and Sophie Edelstein, above n 89.

144 J. Janewa OseiTutu, 'A Sui Generis Regime for Traditional Knowledge: The Cultural Divide in Intellectual Property Law' (2011) 15(1) Marquette Intellectual Property Law Review 147, 155.

145 Ibid 158.

146 Margo A. Bagley, above n 81.

147 Cynthia M Ho, 'Biopiracy and Beyond: A Consideration of Socio-Cultural Conflicts with Global Patent Policies' (2005-2006) 39(3) University of Michigan Journal of Law Reform 433.

148 See, e.g., Communication from Brazil, China, Colombia, Ecuador, India, Indonesia, Peru, Thailand, the ACP Group, and the African Group, Draft Decision to Enhance Mutual Supportiveness Between the TRIPS Agreement and the Convention on Biological Diversity, WTO Doc TN/C/W/59 (19 April 2011). 
would introduce uncertainty into the patent system and would negatively affect not only innovation and economic development but benefit-sharing as well. ${ }^{149}$ In addition, critics of disclosure of origin requirements argue that such measures would be inconsistent with the Agreement on Trade Related Aspects of Intellectual Property ('TRIPS Agreement'). ${ }^{150}$ Critics of patent disclosure requirements argue that they would impose substantive patent requirements over and above those set out in article 27 of the TRIPS Agreement. ${ }^{151}$ Supporters of patent disclosure requirements argue that such provisions are not substantive patent law provisions impacting upon the availability and scope of patent law under the TRIPS Agreement; rather, they are merely 'reasonable procedures and formalities' applicable to the acquisition and maintenance of intellectual property rights under article 62 of the TRIPS Agreement. ${ }^{152}$

In response to the position that patent disclosure requirements are inconsistent with the TRIPS Agreement, a group of like-minded countries has proposed an amendment to the TRIPS Agreement specifically incorporating disclosure of origin provisions in article 29. The proposal aims to establish a mutually supportive relationship between the TRIPS Agreement and the CBD, with an emphasis on the principles of prior informed consent and fair and equitable benefit sharing. ${ }^{153}$ The revised article 29bis, 'Disclosure of Origin of Genetic Resources and/or Associated Traditional Knowledge’, requires member parties

149 Jon Santamauro, 'Reducing the Rhetoric: Reconsidering the Relationship of the TRIPS, CBD and Proposed New Patent Disclosure Requirements Relating to Genetic Resources and Traditional Knowledge' (2007) 3 European Intellectual Property Review 91.

150 Ibid; Graham Dutfield, 'Disclosure of origin: time for a reality check?' in Martha Chouchena-Rojas, Manuel Ruiz Muller, David Vivas and Sebastien Winkler (eds), Disclosure Requirements: Ensuring mutual supportiveness between the WTO TRIPS Agreement and the CBD (IUCN, 2005) 43, 44.

151 Jon Santamauro, above n 149; Graham Dutfield, above n 150, 44. See also, Communication from the United States, Article 27.3(b), Relationship between the TRIPS Agreement and the CBD, and the Protection of Traditional Knowledge and Folklore, WTO Doc IP/C/W/434 (26 November 2004); Communication from the United States, Article 27.3(b), Relationship between the TRIPS Agreement and the CBD, and the Protection of Traditional Knowledge and Folklore, WTO Doc $\mathrm{IP} / \mathrm{C} / \mathrm{W} / 449$ (10 June 2005).

152 Susette Biber-Klemm, Philippe Cullet, Christophe Germann, Andrea Nascimento Muller and Jonathan Curci, 'Flanking Policies in National and International Law' in Susette Biber-Klemm, Thomas Cottier and Danuta Szymura Berglas (eds), Rights to Plant Genetic Resources and Traditional Knowledge: Basic Issues and Perspectives (CABI, 2006) 239, 242.

153 Communication from Brazil, China, Colombia, Ecuador, India, Indonesia, Peru, Thailand, the ACP Group, and the African Group, Draft Decision to Enhance Mutual Supportiveness Between the TRIPS Agreement and the Convention on Biological Diversity, WTO Doc TN/C/W/59 (19 April 2011). 
to have regard to the provisions of the CBD and Nagoya Protocol and, where the subject matter of the patent involves the use of genetic resources and/or associated traditional knowledge, disclose the country of origin and the source providing the genetic resources and/or associated traditional knowledge. ${ }^{154}$ The amendment also proposes applicants provide a copy of an internationally recognised certificate of compliance (as contemplated by the Nagoya Protocol ${ }^{155}$ ) or where such certificate is not available, that applicants provide information regarding compliance with any national requirements relating to prior informed consent and fair and equitable benefit sharing. ${ }^{156}$ The consequences for failing to comply with the requirements set out in the proposed article 29bis may include administrative sanctions, criminal sanctions, fines, compensation for damages or revocation of the patent. ${ }^{157}$

Revised patent examination procedures and disclosure of origin requirements have been implemented at a regional level, for example, in the Andean Community Decision 391-Common Regime on Access to Genetic Resources ${ }^{158}$ and Decision 486-Common Provisions on Industrial Property, ${ }^{159}$ and in the domestic legislation of countries such as India ${ }^{160}$ and Peru. ${ }^{161}$ Despite these efforts, it has become widely acknowledged that, while the intellectual property system can protect some aspects of traditional knowledge, existing intellectual property mechanisms cannot fully respond to the holistic, communal and collective nature of certain forms of traditional knowledge. ${ }^{162}$ Within the western intellectual property framework, knowledge is viewed as a tradeable commodity that is either able to be privately owned or is freely available in the public domain. ${ }^{163}$ This approach is inconsistent with customary laws and the principles held by Indigenous and local communities. ${ }^{164}$

154 Ibid art 29bis(2).

155 See, e.g., Nagoya Protocol art 17.

156 Communication from Brazil, China, Colombia, Ecuador, India, Indonesia, Peru, Thailand, the ACP Group, and the African Group, Draft Decision to Enhance Mutual Supportiveness Between the TRIPS Agreement and the Convention on Biological Diversity, WTO Doc TN/C/W/59 (19 April 2011) art 29bis(2).

157 Ibid art 29bis(5).

158 Decision 391 art 7.

159 Decision 486 art 26.

160 Patents Act 1970 (India) ss 25(1)(j), 25(2)(j) and 64(1)(p).

161 Law 27811 Second Complementary Provision.

162 World Intellectual Property Organization, Intellectual Property Needs and Expectations of Traditional Knowledge Holders: WIPO Report on Fact-Finding Missions on Intellectual Property and Traditional Knowledge 1998-1999 (April 2001),

216; Katie O'Bryan, above n 15, 33; Peter Drahos, above n 58, 234.

163 Cynthia M. Ho, above n 147.

164 Peter Drahos, above n 96, 196. 
The rationale behind the western patent system is to grant an inventor a monopoly right for a limited period of time in return for public disclosure of the invention, with the purpose of such a regime being to reward creators and encourage innovation and creativity. ${ }^{165}$ However, as argued by Drahos, Indigenous and local communities do not need the incentives of western intellectual property rights systems to carry out their innovation, as their cosmologies bind them in duty to country- and place-based innovation. ${ }^{166}$ Drahos suggests that western intellectual property rights have little relevance to Indigenous and local communities who innovate at the level of systems, such as biodiversity, environmental or climate systems, rather than at the level of commodities. ${ }^{167}$ The intellectual property system does not serve Indigenous and local communities and, as demonstrated by WIPO, is inadequate to protect traditional knowledge.

In 2008, the WIPO IGC commissioned a Gap Analysis on the Protection of Traditional Knowledge and this analysis was updated in 2018 ('Gap Analysis'). ${ }^{168}$ The Gap Analysis report identified policy objectives that have been expressed at an international level but have not been formally expressed or affirmed in relation to intellectual property and traditional knowledge. These include:

(i) '[r]ecognising that traditional knowledge systems are valuable forms of innovation';

(ii) '[p]romoting respect for traditional knowledge systems and the cultural and spiritual values of the rights holders';

(iii) '[p]romoting conservation and preservation of traditional knowledge';

(iv) 'preventing misappropriation and unfair use of traditional knowledge';

(v) 'promoting equitable benefit sharing';

(vi) '[e]nsuring that access to, and use of, traditional knowledge is subject to prior informed consent'; and

(vii) '[c]urtailing the grant or exercise of improper intellectual property rights over traditional knowledge'. ${ }^{169}$

165 Attorney General (Cth) v Adelaide Steamship Co [1913] AC 781; Fritz Machlup and Edith Penrose, 'The Patent Controversy in the Nineteenth Century' (1950) 10(1) The Journal of Economic History 1.

166 Peter Drahos, above n 58, 243.

167 Ibid.

168 World Intellectual Property Organization Intergovernmental Committee on Intellectual Property and Genetic Resources, Traditional Knowledge and Folklore, The Protection of Traditional Knowledge: Updated Draft Gap Analysis, Doc No WIPO/ GRTKF/IC/37/6 (20 July 2018) ('Gap Analysis').

169 Ibid Annex 1, 21-2, [76]-[78]. 
Following this, the report identifies the following four key gaps in existing legislation in relation to the protection of traditional knowledge:

(i) the subject matter, that is, traditional knowledge, is not covered under existing intellectual property law;

(ii) Indigenous and local communities are not recognised as right holders and are therefore excluded from the benefits of protection;

(iii) specific forms of protection, such as disclosure of origin or protection against unjust enrichment, misappropriation or misuse of traditional knowledge, are not provided under existing intellectual property law; and

(iv) an absence of entitlement to obtain benefits derived from the use of traditional knowledge. ${ }^{170}$

The report recognises that traditional knowledge is often excluded from conventional subject matters of intellectual property. ${ }^{171}$ This is the result of traditional knowledge generally being considered to be in the public domain and obvious to a person skilled in the relevant art. Many conventional forms of intellectual property rights, such as patents, require the identification of specific inventors and a specific inventive step and, therefore, fail to accommodate innovation that is cumulatively developed over generations and held collectively by a community (or group of individuals within a community). ${ }^{172}$ Intellectual property rights are typically granted to an individual or small group of recognised individuals. With the exceptions of geographical indications, collective trademarks and the protection of confidential information, the collective rights or interests of an Indigenous or local community are not recognised within the intellectual property system. ${ }^{173}$ In order to adequately protect traditional knowledge under the existing intellectual property system, it is necessary to recognise that an Indigenous or local community may have rights over traditional knowledge that is distinctly associated with them. ${ }^{174}$

The Gap Analysis report then turns to a consideration of the options that exist or may be developed to address the identified gaps. The report canvasses a number of options at the international level, including binding international instruments; interpretations or elaborations of existing instruments; a non-binding instrument; high-level resolutions; guidelines or model laws; and coordination of national legislative developments and capacity building

170 Ibid Annex 1, 23, [80].

171 Ibid Annex 1, 23-4, [82]-[89].

172 Ibid Annex 1, 24, [86]. See also, Darrell A. Posey, 'Protecting Indigenous Peoples' Rights to Bio Diversity: People, Property and Bioprospecting' (1996) 38(8) Environment 6, 37; Natalie Stoianoff, above n 103, 32.

173 Gap Analysis Annex 1, 24-5, [90].

174 Ibid Annex 1, 25, [92]. 
activities. ${ }^{175}$ The report also briefly identifies options at a regional level, such as the development of legal instruments, including sui generis instruments; model laws, protocols, and guidelines; and regional initiatives and programs to support capacity building. ${ }^{176}$ Options at a national level are also identified, such as legislation including sui generis instruments; policy and administrative tools; model protocols and guidelines; and capacity building programs. ${ }^{177}$

Several options for protection of traditional knowledge outside the intellectual property system have been considered in the literature, including compensatory liability regimes, ${ }^{178}$ a global bio-collecting society, ${ }^{179}$ reciprocity agreements ${ }^{180}$ and sui generis regimes. ${ }^{181}$ Under the terms of a compensatory liability regime, traditional knowledge would be treated as technical know-how that does not meet the requirements for patent or copyright protection. A compensatory liability regime would provide Indigenous and local communities with non-exclusive rights for a limited time to prevent second comers from entering a market with an un-original imitation of their product, and provide rights holders with reasonable compensation from follow-on inventors who make improvements on the traditional knowledge. ${ }^{182}$ Such a model would operate well in an environment where traditional knowledge holders are organised and easily identifiable as a community and possess traditional knowledge that is of commercial value. ${ }^{183}$ However, compensatory liability regimes have limited application where traditional knowledge does not have immediate commercial value, as a limited right for a specific period may not capture the benefits generated under long-term research and development activities. ${ }^{184}$ Further, difficulties may arise where the true rights holders cannot be identified or where the contribution of traditional knowledge to a follow-on invention may not be easily quantified. ${ }^{185}$ Finally, such a regime does not provide protection where such traditional knowledge does not have any commercial value, where the traditional knowledge is considered secret or

175 Ibid Annex 1, 32-9.

176 Ibid Annex 1, 39.

177 Ibid Annex 1, 40.

178 Krishna Ravi Srinivas, above n 2.

179 Peter Drahos, 'Indigenous Knowledge, Intellectual Property and Biopiracy: Is a Global Bio-Collecting Society the Answer' (2000) 22(6) European Intellectual Property Review 245.

180 Krishna Ravi Srinivas, above n 2, 103.

181 Natalie Stoianoff, above n 103, 38; Natalie P. Stoianoff and Alpana Roy, above n 29.

182 Krishna Ravi Srinivas, above n 2, 98.

183 Ibid 100.

184 Ibid 99.

185 Ibid. 
sacred or where the relevant Indigenous or local community wants to prevent any commercial exploitation of its traditional knowledge.

Drahos has proposed the creation of a global bio-collecting society to regulate the use and protection of traditional knowledge. ${ }^{186}$ The bio-collecting society would take the form of a private, multilateral agency outside of any treaty negotiation, with optional membership open to both Indigenous communities and corporations. ${ }^{187}$ The purpose of the collecting society would be to encourage a 'process of private ordering among companies and indigenous groups' and encourage corporate social responsibility. ${ }^{188}$ The proposed society could provide a number of services, including a repository for registers of traditional knowledge, assistance in negotiations, a monitoring service to report on the use of traditional knowledge, a dispute resolution mechanism and a standard-setting body responsible for developing codes of conduct. ${ }^{189}$ Establishing a global bio-collecting society would bypass the complex and drawn-out treaty negotiation process and encourage the direct engagement of Indigenous communities and corporations. ${ }^{190}$ However, the success of such a society is dependent on its membership and the active participation of both Indigenous communities and corporations, and it is not clear whether either group is interested in this proposal. ${ }^{191}$ While a number of incentives exist to encourage participation by both Indigenous communities and corporate interests in such a society, ${ }^{192}$ the WIPO study on the needs and expectations of traditional knowledge holders has identified that Indigenous and local communities generally favour an approach that will obtain rights through more formal legal mechanisms, such as treaties or stand-alone legislation. ${ }^{193}$

Another option for the protection of traditional knowledge is the use of separate agreements between source and user countries specifying the extent to which the countries will protect traditional knowledge, including the scope and form of such protection. ${ }^{194}$ It is envisaged that source countries may negotiate reciprocity agreements as a group along regional lines, even potentially setting

186 Peter Drahos, above n 179.

187 Ibid 248.

188 Ibid.

189 Ibid.

190 Ibid 249.

191 Ibid.

192 Ibid.

193 World Intellectual Property Organization, Intellectual Property Needs and Expectations of Traditional Knowledge Holders: WIPO Report on Fact-Finding Missions on Intellectual Property and Traditional Knowledge 1998-1999 (April 2001) 225-226. See also, Krishna Ravi Srinivas, above n 2, 100.

194 Krishna Ravi Srinivas, above n 2, 103. 
up regional agencies to manage negotiations. ${ }^{195}$ Regional approaches are used in areas such as trade and commerce, where bilateral and regional trading agreements are common and have the benefit of being more flexible in their approach to the issue. However, as with any contract, the outcome of such an agreement will be vulnerable to any inequality in the bargaining power of the parties involved. ${ }^{196}$ Reciprocity agreements may be of limited value if they cannot accommodate the diversity of views across a number of Indigenous and local communities within a region and, importantly, developing nations have expressed a desire to negotiate solutions at a global level. ${ }^{197}$ The inadequacy of the intellectual property system and other proposed solutions to protect traditional knowledge has reinforced the need for a sui generis regime operating on the basis of prior informed consent and mutually agreed terms. ${ }^{198}$ The next section of this chapter will address the rationale behind the adoption of sui generis regimes and address some of the criticisms in the literature.

\section{F. SUI GENERIS REGIMES}

The use of sui generis regimes for the protection of traditional knowledge has been endorsed by both the Conference of the Parties to the CBD ${ }^{199}$ and WIPO ${ }^{200}$ and is supported by many Indigenous and local communities across the world. WIPO has engaged in consultation with Indigenous and local communities on the needs and expectations of traditional knowledge holders to inform the development of a framework for the protection of traditional knowledge. ${ }^{201}$ The fact-finding missions carried out by WIPO involved informants from 28 countries and reinforced the importance of a sui generis regime of rights to protect traditional knowledge. ${ }^{202}$

195 Ibid.

196 Peter Drahos, above n 179.

197 Krishna Ravi Srinivas, above n 2, 104.

198 Natalie Stoianoff, above n 103, 38; Natalie P. Stoianoff and Alpana Roy, above n 29,745 .

199 Conference of the Parties to the Convention on Biological Diversity, Decision VIII/5: Article 8(j) and related provisions, Doc No UNEP/CBD/COP/DEC/VIII/5 (15 June 2006), accessed 30 October 2019 at https:/www.cbd.int/doc/decisions/cop-08/ cop-08-dec-05-en.pdf.

200 World Intellectual Property Organization General Assembly, Matters Concerning the Intergovernmental Committee on Intellectual Property and Genetic Resources, Traditional Knowledge and Folklore, 38th (19th Ordinary) sess, Agenda Item 28, UN Doc WIPO/GRTKF/IC/15/REF-DECISION 28 (1 October 2009).

201 World Intellectual Property Organization, Intellectual Property Needs and Expectations of Traditional Knowledge Holders: WIPO Report on Fact-Finding Missions on Intellectual Property and Traditional Knowledge 1998-1999 (April 2001).

202 Ibid 217. 
Sui generis regimes can be developed and adapted to address the needs and expectations of diverse Indigenous and local communities. ${ }^{203}$ Where such regimes are based on the principles of self-determination, prior informed consent and mutually agreed terms, a sui generis regime can empower Indigenous and local communities and prevent misappropriation and exploitation of traditional knowledge within a framework based on customary law and practices. ${ }^{204}$ Establishing a sui generis regime for the protection of traditional knowledge also provides a degree of certainty for Indigenous and local communities, as well as other stakeholders. A sui generis regime may, therefore, encourage legitimate use by third parties while protecting the integrity of traditional knowledge and returning benefits to Indigenous and local communities. ${ }^{205}$

Concerns have been raised as to the potential of sui generis regimes to further reinforce the cultural divide between traditional knowledge holders and potential users of traditional knowledge ${ }^{206}$ and to impose western systems of governance and bureaucracy over traditional knowledge. ${ }^{207}$ There exists a valid concern that the use of sui generis regimes may disempower Indigenous and local communities and perpetuate colonialism and dispossession. ${ }^{208}$ However, the same argument may also be used in relation to the use of the western intellectual property system to protect traditional knowledge. Indigenous and local communities have experienced many wrongs (and continue to do so), including acts of biopiracy, and the existing systems have failed to adequately protect traditional knowledge. The use of sui generis regimes is supported by Indigenous and local communities and sui generis regimes based on customary law and protocols may operate to empower Indigenous and local communities and support self-determination.

Another criticism that is often raised is that sui generis regimes may operate to reduce access to affordable knowledge goods, including for Indigenous and local communities. ${ }^{209}$ However, failure to implement sufficient protections for traditional knowledge using a sui generis regime may have an even greater impact. The grant of patent rights over traditional knowledge may lead to

203 Christoph Antons, 'Sui Generis Protection for Plant Varieties and Traditional Agricultural Knowledge: The Example of India' (2007) 12 European Intellectual Property Review 480, 485.

204 Chidi Oguamanam, International Law and Indigenous Knowledge: Intellectual Property, Plant Biodiversity and Traditional Medicine (University of Toronto Press, 2006) 219.

205 Ibid 4, 217-218.

206 Ibid 214.

207 Peter Drahos, above n 122, 94, 96.

208 Ibid 97.

209 J. Janewa OseiTutu, above n 144, 154. 
increased demand for biological resources associated with traditional knowledge and, therefore, result in reduced availability of biological resources and increased prices for Indigenous and local communities. ${ }^{210}$ The degree of certainty offered by such a regime will depend on the level of consensus achieved as to the scope of rights available and the beneficiaries of protection. ${ }^{211}$ The lack of international recognition, and the territorial nature of any legislation, may also limit the effectiveness of sui generis regimes; ${ }^{212}$ this highlights the need for international coordination in the development of such frameworks for the protection of traditional knowledge. Finally, there are concerns that the process of negotiating a framework for the protection of traditional knowledge at the international level will take too long and result in an unwieldy regime. ${ }^{213}$ However, while the process may be difficult, there is precedent for the development of a new regime; new forms of intellectual property have been readily created in the past, including protection for semiconductors and plant varieties. ${ }^{214}$

The theory of corrective justice supports the implementation of sui generis regimes for the protection of traditional knowledge. ${ }^{215}$ Munzer sets out the criteria upon which rights in traditional knowledge may be available on the grounds of corrective justice as follows:

(a) some wrongs have been committed against an indigenous group, some or all of its members, their successors, or both;

(b) the wrongdoers or their successors are identifiable as a group, individual members of a group, some other entity, or some combination of these;

(c) the wrongs unjustifiably caused harm to an indigenous people or some of its members, or both; and

(d) those harmed are identifiable as an indigenous group or as individual members of an indigenous group, or both. ${ }^{216}$

Munzer identifies two additional criteria for intellectual property rights in traditional knowledge. First, no excuse should be available such that the wrongdoers or their successors lack a moral duty to rectify their wrongs. Second,

\footnotetext{
210 Cynthia M. Ho, above n 147, 465.

211 J. Janewa OseiTutu, above n 144, 155.

212 Christoph Antons, above n 203, 485.

213 Krishna Ravi Srinivas, above n 2, 105.

214 Peter Drahos, above n 96, 194.

215 Stephen R. Munzer, above n 25; Natalie P. Stoianoff and Alpana Roy, above n 29; Jules L. Coleman, 'Intellectual Property and Corrective Justice' (1992) 78 Virginia Law Review 283; Wendy J. Gordon, 'On Owning Information: Intellectual Property and the Restitutionary Impulse' (1992) 78 Virginia Law Review 149, 149.

216 Stephen R. Munzer, above n 25, 61.
} 
intellectual property rights in traditional knowledge would, in principle, be part of an effective and reasonably efficient means of compensating or restoring justice to the Indigenous community involved. ${ }^{217}$

Sanderson identifies the suppression of those institutions that positively affirm Indigenous values, cultures and identities as one of the greatest wrongs perpetrated against Indigenous and local communities. ${ }^{218}$ These intentional wrongs were, and continue to be, committed by colonial governments that fail to engage in a just manner with Indigenous people who possess their own systems of government. ${ }^{219}$ This wrong manifests itself in the denial of choice for Indigenous communities about how best to form and shape their communities, identity and cultural values. ${ }^{220}$

These past and contemporary wrongs may be addressed using the principles of corrective justice. Given that the harm or wrong in question is trans-generational, the benefit or remedy offered should be trans-generational as well. ${ }^{221}$ Conferring rights in traditional knowledge through a sui generis regime can support self-determination and empower Indigenous and local communities. ${ }^{222}$ Rights in traditional knowledge may form part of a package that supports the return to Indigenous and local people of modern institutions that affirm Indigenous values and practices and, therefore, serve as a form of corrective justice to address the many wrongs suffered by Indigenous and local peoples. ${ }^{223}$

The importance of sui generis regimes has been recognised globally, with regimes providing protection for traditional knowledge being developed and implemented at international, regional and domestic levels. As mentioned previously, the Nagoya Protocol entered into effect on 12 October 2014, requiring parties to implement mechanisms governing access and benefit sharing, and progress is being made at WIPO with the drafting of a legal framework for the protection of traditional knowledge. At a regional level, model laws for the protection of traditional knowledge have been developed in Africa ${ }^{224}$ and

217 Ibid 62.

218 Douglas Sanderson, above n 26, 93.

219 Ibid 103.

220 Ibid 119.

221 Stephen R. Munzer, above n 25, 66.

222 Ibid 81.

223 Douglas Sanderson, above n 26, 93.

224 African Union, African Model Legislation for the Protection of the Rights of Local Communities, Farmers and Breeders, and for the Regulation of Access to Biological Resources 2000; African Regional Intellectual Property Organisation, Swakopmund Protocol on Protection of Traditional Knowledge and Expressions of Folklore 2010. 
the Pacific Islands, ${ }^{225}$ and the Andean Community has implemented Decision 391-Common Regime on Access to Genetic Resources, establishing an access and benefit-sharing regime governing genetic resources and associated know-how, innovations and traditional practices of indigenous peoples. ${ }^{226}$ Finally, various countries have developed and implemented sui generis laws that provide varying degrees of protection for traditional knowledge, including India, ${ }^{227}$ Peru, ${ }^{228}$ Brazil, ${ }^{229}$ Ethiopia, ${ }^{230}$ Kenya, ${ }^{231}$ the Philippines, ${ }^{232}$ Portugal, ${ }^{233}$ Panama $^{234}$ and Costa Rica. ${ }^{235}$ While the content and form of each of these regimes vary, there are several common elements that can be identified. Typically, these laws set out the purpose of the regime and the subject matter of protection, including definitions of 'traditional knowledge', the knowledge holders and intended beneficiaries (though the exact terms and the actual definitions used vary across the different laws); the scope of protection available; access and benefit-sharing provisions, including requirements for prior informed consent and mutually agreed terms; provisions relating to the creation of databases of traditional knowledge; disclosure obligations on user parties; creation or appointment of a national authority to administer the laws; provisions relating to dispute resolution and sanctions; exemptions; capacity building; interaction with other laws, including the role of customary law; and cross-border issues. ${ }^{236}$

225 Pacific Community Model Law for the Protection of Traditional Knowledge and Expressions of Culture 2002.

226 Decision 391.

227 Biological Diversity Act 2002 (India); The Scheduled Tribes and Other Traditional Forest Dwellers (Recognition of Forest Rights) Act 2006 (India).

${ }_{228}$ Law No. 27811 Introducing a Protection Regime for the Collective Knowledge of Indigenous Peoples Derived from Biological Resources 2002 (Peru).

${ }_{229}$ Provisional Measure No. 2186-16 of 2001 Regulating Access to the Genetic Heritage, Protection of and Access to Associated Traditional Knowledge (Brazil); Law No. 13,123 of 20 May 2015 (Access and Benefits Sharing of Genetic Resources and Associated Traditional Knowledge) (Brazil).

230 Access to Genetic Resources and Community Knowledge, and Community Rights Proclamation No. 482/2006 (Ethiopia).

231 Protection of Traditional Knowledge and Cultural Expressions Act 2016 (Kenya).

${ }_{232}$ Indigenous Peoples Rights Act 1997 (Philippines).

233 Decree Law No. 118 of 2002 Establishing a Legal Regime of Registration, Conservation, Legal Custody and Transfer of Plant Endogenous Material (Portugal).

${ }^{234}$ Law No. 20 of 26 June 2000, on Special System for the Collective Intellectual Property Rights of Indigenous Peoples for the Protection and Defense of their Cultural Identity and their Traditional Knowledge (Panama).

235 Law No. 7788 of 1998 on Biodiversity (Costa Rica).

236 Note that not all the laws listed above contain each of these provisions. The list provided sets out provisions that are common amongst most of the examples. 
India and Peru have led the way in implementing stand-alone laws that provide protection to traditional knowledge associated with or connected to biological resources. The legal frameworks established in each country draw on a range of tools to achieve this objective, including the use of access and benefit-sharing regimes and databases. However, the countries have taken very different approaches in the design and implementation of their respective schemes. This book will present a comparative analysis of the legal regimes established in India and Peru for the protection of traditional knowledge, focusing on the following common themes: (i) the history and objectives of the regime; (ii) the institutions and funds established for the purpose of implementing the regime; (iii) access and benefit sharing; and (iv) the role of databases. A comparative analysis focusing on these themes may serve two purposes. First, member countries to the Nagoya Protocol have obligations to implement measures regulating access to and the use of traditional knowledge and the sharing of benefits arising out of such use. The comparative analysis set out in this book examines how India and Peru have approached the issue and allows other countries to learn from their experience. Second, and most importantly, the comparative analysis set out in this book can be used to inform the development of a sui generis regime for the protection of traditional knowledge in other countries that empower Indigenous and local peoples, promotes self-determination, and returns to communities institutions that affirm Indigenous values and practices.

\section{G. INDIA AND PERU}

The comparative analysis set out in this book examines how India and Peru have approached the issue of protecting traditional knowledge and allows other countries and Indigenous or local communities to learn from their experience. The comparative analysis was approached, first, by studying the political, historical, economic, and social contexts that frame the legal systems of India and Peru, including the international drivers behind implementation of the respective regimes. Second, the law as it is expressed in words was analysed to identify the key features, similarities and differences between each regime. Third, the project evaluated how the law actually operates within each jurisdiction (insofar as this was possible), including a consideration of the implementation of each regime. Finally, the data was synthesised to develop comparative observations and identify key lessons arising out of the experience of India and Peru. ${ }^{237}$ The comparative analysis builds upon Dutfield's

237 This approach reflects the methodology described in Edward J Eberle, 'The Method and Role of Comparative Law' (2009) 8(3) Washington University Global Studies Law Review 451. 
framework of questions or data points for assessing systems for the protection of traditional knowledge $\mathrm{e}^{238}$ and is structured across four themes: history and objectives; institutions and funds; access and benefit sharing; and databases and registers.

The key legislation reviewed in each jurisdiction is as follows:

- Biological Diversity Act 2002 (India);

- Biological Diversity Rules 2004 (India);

- Patents Act 1970 (India);

- Law No. 27811 Introducing a Protection Regime for the Collective Knowledge of Indigenous Peoples Derived from Biological Resources 2002 (Peru);

- Law No. 28216 Act on the Protection of Access to Peruvian Biological Diversity and the Collective Knowledge of Indigenous Peoples 2004 (Peru).

While there are a number of countries that could have been chosen for comparison, the selection of India and Peru was informed by a number of factors. Both countries are megadiverse, both have identifiable Indigenous or local peoples who have experienced colonisation by a foreign power, and in 2002 both countries implemented regimes that provide some measure of protection for traditional knowledge associated with biological resources. These similarities mean that the Biological Diversity Act 2002 (BDA) in India and Law 27811 in Peru are useful comparators for the purpose of identifying globally applicable lessons for other countries in the design and implementation of regime for the protection of traditional knowledge.

Peru is classified as megadiverse ${ }^{239}$ and is home to around 20,000 higher plant species, of which 5,509 are endemic. ${ }^{240}$ According to submissions made to the World Trade Organization, the 'number of species in Peru with a current or potential industrial application is high at 2642' with uses including food,

${ }^{238}$ Graham Dutfield, 'Developing and Implementing National Systems for Protecting Traditional Knowledge: A Review of Experiences in Selected Developing Countries' (UNCTAD Expert Meeting on Systems and National Experiences for Protecting Traditional Knowledge, Innovations and Practices, 2000) 14.

239 Russell A. Mittermeier, Cristina Goettsch Mittermeier and Patricio Robles Gil, Megadiversity: Earth's Biologically Wealthiest Nations (Conservation International, 1999).

240 León B. et al, 'El libro rojo de las plantas endémicas del Perú', Revista Peruana de Biología, special edition, Vol 13, No 2: 9s-22s (National University of San Marcos (UNMSM), Biological Sciences Faculty: 2006), ISSN 1561-0837 cited in Communication from Peru, Combating Biopiracy - The Peruvian Experience, WTO Doc IP/C/W/493 (19 September 2007) 1. 
medicine, timber, fertilisers, perfumes, cosmetics, tanning and colourants. ${ }^{241}$ Peru is home to approximately 31.9 million people ${ }^{242}$ and is ethnically and culturally diverse, with 72 Indigenous ethnic groups across the Andes and Amazon making up an estimated one-third of the total population. ${ }^{243}$ Of the Indigenous population, 97.8 per cent is Andean (of which 90.9 per cent are of Quechuan origin and 9.9 per cent Aymara origin) and 2.1 per cent are Amazonian (including Achuar, Aguarana, Ashaninka, Shipibo and Huambisa peoples). ${ }^{244}$

The country has a long history of colonisation from the Inca in the fifteenth century, to the Spanish conquistadors in the early 1530s followed soon thereafter by the Spanish Crown. ${ }^{245}$ Modern Peru declared independence from the Spanish in $1824 ;^{246}$ however this did not result in a complete withdrawal of settlers leaving modern Peru an 'enclave territory'. ${ }^{247}$ The post-independence transition has seen significant political turmoil including internal war which has further weakened Indigenous institutional mechanisms and politics in Peru. ${ }^{248}$ Despite the limited form of decolonization following independence, the importance of self-determination is recognised in the Political Constitution of Peru which provides that the peasant and native communities are 'autonomous in their organisation, communal work and the use and free disposal of their lands, as well as economic and administrative matters within the framework established by law' ${ }^{249}$ Importantly, the Constitution also acknowl-

\footnotetext{
${ }^{241}$ Communication from Peru, Combating Biopiracy-The Peruvian Experience, WTO Doc IP/C/W/493 (19 September 2007) 1.

${ }^{242}$ As at 2018. See The World Bank, Peru (2018), accessed 1 November 2019 at http://data.worldbank.org/country/peru.

${ }_{243}$ Communication from Peru, Combating Biopiracy-The Peruvian Experience, WTO Doc IP/C/W/493 (19 September 2007) 1; Manuel Ruiz 'Peru: Seeking benefit sharing through a defensive approach - the experience of the National Commission for the Prevention of Biopiracy' in Manuel Ruiz and Ronnie Vernooy (eds), The Custodians of Biodiversity: Sharing Access and Benefits of Genetic Resources (Earthscan, 2012) $43,43$.

${ }^{244}$ Communication from Peru, Combating Biopiracy-The Peruvian Experience, WTO Doc IP/C/W/493 (19 September 2007) 1.

${ }_{245}$ Christopher Heaney, 'Conquests of Peru' in Oxford Research Encyclopaedia of Latin American History (September 2016).

246 Daniel Masterson, The History of Peru (Greenwood Press, 2009) 12.

247 The term 'enclave territory' is used to refer to those territories where 'colonial settlers did not withdraw'. See Chidi Oguamanam, Intellectual Property in Global Governance: A Development Question (Routledge, 2012) 142.

248 Maritza Paredes, 'Weak Indigenous Politics in Peru' CRISE: Centre for Research on Inequality, Human Security and Ethnicity, University of Oxford (CRISE Working Paper No. 22, April 2008).

249 Political Constitution of Peru 1993 art 89.
} 
edges that the State 'respects the cultural identity of the peasant and native communities'. ${ }^{250}$

India is also classified as megadiverse $\mathrm{e}^{251}$ and the majority of the population, in particular tribal communities, is reliant on biological resources for its livelihood. ${ }^{252}$ Following surveys of approximately 65 to 70 per cent of the geographical area of the country, it is estimated that India accounts for between seven and eight per cent of the world's recorded species. ${ }^{253}$ India is the centre of origin for a number of plants, including the pigeon pea, eggplant and cucumber, ${ }^{254}$ and the Botanical Survey of India has recorded over 47,000 species of plants. ${ }^{255}$ In addition, the Zoological Survey of India has identified over 90,000 species of animals. ${ }^{256}$ India covers more than 3.2 million square kilometres $^{257}$ and is home to more than 1.2 billion people. ${ }^{258}$ The country is culturally diverse, with tribal people estimated to make up 8.6 per cent of the population, with over 700 Scheduled Tribes designated under the Constitution of India.$^{259}$ India also has a long colonial history following the arrival of the East India Company in the early 1600s, with modern India achieving political independence in 1947 following the withdrawal of the British in a form of

250 Ibid.

251 Russell A. Mittermeier, Cristina Goettsch Mittermeier and Patricio Robles Gil, above $\mathrm{n} 239$.

252 Kanchi Kohli (ed), Understanding the Biological Diversity Act 2002: A Dossier (Kalpavriksh, GRAIN and IIED, 2006) 8.

253 Submission by India, Protection of Biodiversity and Traditional KnowledgeThe Indian Experience, WTO Doc WT/CTE/W/156 IP/C/W/198 (14 July 2000) [3].

${ }^{254}$ Graham Dutfield, Intellectual Property, Biogenetic Resources and Traditional Knowledge (Earthscan, 2004) 166.

255 Submission by India, Protection of Biodiversity and Traditional KnowledgeThe Indian Experience, WTO Doc WT/CTE/W/156 IP/C/W/198 (14 July 2000) [3].

256 Zoological Survey of India, Background (31 January 2015), accessed 1 November 2019 at http://zsi.gov.in/App/content.aspx?link=153.

257 Office of the Registrar General and Census Commissioner, Government of India, Population Enumeration Data: A-1 Number of Villages, Towns, Households, Population and Area, accessed 1 November 2019 at http:/www.censusindia.gov.in/ 2011 census/population_enumeration.html.

258 Office of the Registrar General and Census Commissioner, Government of India, Census of India 2011: Primary Census Abstract Figures at a Glance-India, accessed 1 November 2019 at http://www.censusindia.gov.in/2011census/PCA/PCA_Highlights/ pca_highlights_file/India/5Figures_at_glance.pdf.

${ }^{259}$ Constitution of India 1949 art 366(25). The essential characteristics required for classification as a 'Scheduled Tribe' are: '(a) indications of primitive traits; (b) distinctive culture; (c) shyness of contact with the community at large; (d) geographical isolation; and (e) backwardness'. See also Ministry of Tribal Affairs Statistics Division (Government of India), Statistical Profile of Scheduled Tribes in India 2013, 1, accessed 4 November 2019 at https://tribal.nic.in/ST/StatisticalProfileofSTs2013.pdf. 
decolonisation. ${ }^{260}$ However, the legacy of British rule remains in the form of established laws and bureaucracy. As observed by Kohli, the 'civil service constituted the heart of the state that India inherited from the colonial period, and India's 'new' civil service was essentially built on this colonial base.'261 While the civil service in India has contributed to effective government and political stability, ${ }^{262}$ this legacy of colonialism may limit opportunities for self-determination and customary forms of governance particularly by tribal peoples.

The rights of minorities are enshrined in the Constitution of India, with specific provisions establishing the right to conserve distinct languages and cultures. ${ }^{263}$ In addition, special protections are provided for Scheduled Tribes, with seats reserved in the Parliament and Legislative Assemblies of the states for members of Scheduled Tribes. ${ }^{264}$ The Constitution of India also provides for local self-governance with amendments enacted to empower local communities in decision making. ${ }^{265}$ While the English language has been retained post-independence as an official language for the purposes of court proceedings, legislation and regulations, ${ }^{266}$ the cultural and linguistic diversity of India is also reflected in the Constitution, with Hindi designated as the official language ${ }^{267}$ and an additional 21 recognised languages. ${ }^{268}$

While there are similarities between India and Peru, there are also significant differences, both from a legal and a cultural perspective. Indeed, as observed by Oguamanam, Indigenous peoples in enclave and non-enclave territories have 'different interests and emphases ... which are often dictated by the political contexts in which they operate. ${ }^{269}$ These geographical, sociological,

\footnotetext{
260 John McLeod, The History of India (Greenwood Press, 2002) 127.

261 Atul Kohli, Democracy and Development in India: From Socialism to Pro-Business (Oxford University Press, 2009) 5.

262 Ibid.

263 Constitution of India 1949 art 29(1).

264 Ibid art 330. A Commission for Scheduled Tribes is established under art $338 \mathrm{~A}(1)$ of the Constitution of India to, inter alia, investigate and monitor safeguards put into place for Scheduled Tribes and make recommendations on measures that may be taken by the government to secure the "protection, welfare and economic development' of Scheduled Tribes.

265 The Constitution (Seventy-third Amendment) Act 1992 (India) amended the Constitution to introduce Part IX dealing with 'The Panchayats'. The Constitution (Seventy-fourth Amendment) Act 1992 (India) introduced Part IXA dealing with 'The Municipalities'.

266 Constitution of India 1949 art 348(1).

267 Ibid art 343(1).

268 Ibid art 344(1), Sch 8.

269 Chidi Oguamanam, 'Protecting indigenous knowledge in international law: solidarity beyond the nation-state' (2004) 8(1) Law Text Culture 191, 214.
} 
economic, cultural and political factors, including important differences in each country's experience of independence and indigeneity, must be taken into account when considering the outcomes of the comparative analysis. ${ }^{270}$ While there are inherent dangers and limitations associated with any comparative study, these dangers do not prevent the identification of meaningful outcomes from a comparative analysis. ${ }^{271}$ As argued by Watson, 'legal transplants - the moving of a rule or system of law from one country to another, or from one people to another - have been common since the earliest recorded history'. ${ }^{272}$ The literature supports the value of considering foreign jurisdictions as a source of legal transplants, even where there are 'great material and cultural differences between the donor and recipient societies'. ${ }^{273}$

Recognising the value of understanding cultural diversity in a world increasingly driven by the process of globalisation, ${ }^{274}$ the outcomes of the comparative analysis are interpreted within a framework of self-determination and legal pluralism. ${ }^{275}$ This approach allows for the appreciation of differences and interaction between legal systems (both national and international) and between legal and non-legal sources, ${ }^{276}$ including the importance of customary law. 277

270 Otto Kahn-Freund, 'On Uses and Misuses of Comparative Law' (1974) 37(1) The Modern Law Review 1; Alan Watson, Legal Transplants: An Approach to Comparative Law (Scottish Academic Press, 1974); Chidi Oguamanam, above n 269.

271 Alan Watson, Legal Transplants: An Approach to Comparative Law (Scottish Academic Press, 1974) 10.

272 Ibid 21.

273 George Mousourakis, 'Transplanting Legal Models across Culturally Diverse Societies: A Comparative Law Perspective' (2010) 57 Osaka University Law Review 87, 96; Alan Watson, above n 271, 96; Edward J. Eberle, above n 237, 465.

274 George Mousourakis, above n 273, 90.

275 Werner Menski, Comparative Law in a Global Context: The Legal Systems of Asia and Africa (Cambridge University Press, 2nd ed, 2006).

276 Ibid.

277 Masaji Chiba, Legal Cultures in Human Society: A Collection of Articles and Essays (Shinzansha International, 2002) 7-8. Other theoretical frameworks were considered when scoping this project, including property theory and post-colonialism. While these theories provide, to varying extents, a useful frame within which to view the concept of rights in traditional knowledge, there were specific reasons why these frameworks were considered inappropriate for the purpose of this project. While Carpenter et al outline a case for the use of property theory as the foundation of protection of traditional knowledge, the author finds the arguments put forward by Munzer and Raustalia more compelling. Munzer and Raustalia argue that property theory only provides support for a limited bundle of rights in traditional knowledge. See Kristen A. Carpenter, Sonia K. Katyal and Angela R. Riley, 'In Defense of Property' (2009) 118 The Yale Law Journal 1022; Stephen R. Munzer and Kal Raustiala, 'The Uneasy Case for Intellectual Property Rights in Traditional Knowledge’ (2009-2010) 27 Cardozo 
UNDRIP recognises the right of Indigenous peoples to protect their traditional knowledge. ${ }^{278}$ Furthermore, rights in intellectual property are expressly protected under the terms of the Universal Declaration of Human Rights $^{279}$ and the International Covenant on Economic, Social and Cultural Rights (ICESCR). ${ }^{280}$ Self-determination is one of the most fundamental of human rights ${ }^{281}$ and is recognised as such in article 1 of both the International Covenant on Civil and Political Rights ${ }^{282}$ (ICCPR) and ICESCR. A framework based on principles of self-determination and pluralism could support the right of Indigenous and local peoples to control access to traditional knowledge in accordance with customary laws and practices and subject to prior informed consent and mutually agreed terms. ${ }^{283}$ Full recognition of the rights of Indigenous and local peoples in traditional knowledge requires more than a few amendments to the existing intellectual property system; a framework based on self-determination and legal pluralism could provide an 'enduring, fundamental, inalienable and universal entitlement' that operates as corrective justice. ${ }^{284}$ Self-determination recognises the importance of customary law and

Arts and Entertainment Law Journal 37, 97. Post-colonial theory provides a useful framework for consideration of the effects of colonialism and colonial laws and how they continue to be used in countries in a post-colonial context. Post-colonialism was rejected as a theoretical framework for this project on the grounds that many countries with significant Indigenous peoples, including Australia, are still subject to colonialism. See Peter Fitzpatrick and Eve Darian-Smith, 'Laws of the Postcolonial: An Insistent Introduction' in Peter Fitzpatrick and Eve Darian-Smith (eds), Laws of the Postcolonial (The University of Michigan Press, 1999) 1, 4; Alpana Roy, 'Postcolonial Theory and Law: A Critical Introduction' (2008) 29 Adelaide Law Review 315, 319; Margaret Davies, Asking the Law Question (LawBook Co, 3rd ed, 2008), 285; Irene Watson, 'Indigenous Peoples' Law-Ways: Survival Against the Colonial State' (1997) 8 The Australian Feminist Law Journal 39, 50.

278 UNDRIP art 31(1).

279 Universal Declaration of Human Rights, GA Res 217A(III), UN GAOR, 3rd sess, 1st plen mtg, UN Doc A/810 (10 December 1948) art 27.

280 International Covenant on Economic, Social and Cultural Rights, opened for signature 16 December 1966, 993 UNTS 3 (entered into force 3 January 1976) ('ICESCR') art 51(1)(b)-(c).

${ }^{281}$ Jill Webb, 'Indigenous Peoples and the Right to Self-Determination' (2012) 13 Journal of Indigenous Policy 75, 75.

282 International Covenant on Civil and Political Rights, opened for signature 19 December 1966, 999 UNTS 171 (entered into force 23 March 1976) art 1.

283 Rosemary J Coombe, 'Intellectual Property, Human Rights and Sovereignty: New Dilemmas in International Law posed by the Recognition of Indigenous Knowledge and the Conservation of Biodiversity' (1998) 6 Indiana Journal of Global Legal Studies $59,79$.

284 Laurence R. Helfer, 'Toward a Human Rights Framework for Intellectual Property' (2006-2007) 40 University of California Davis Law Review 971, 993; Committee on Economic, Social and Cultural Rights, Human rights and intellectual 
practices in the protection of traditional knowledge. By interpreting the outcomes of the comparative analysis within the framework of self-determination and pluralism, the book takes into account different legal systems - including the conflict between individual and collective rights - and allows for the incorporation of customary law into any proposal for the protection of traditional knowledge.

\section{H. CHAPTER OUTLINE}

The book is set out across six chapters. This chapter presents the research questions and reviews the literature in the field to provide the context within which the research is conducted. The outcomes of the comparative analysis are set out across four chapters. Chapter 2 presents a comparative analysis of the scope and objectives of the regimes established in India and Peru. The analysis set out in Chapter 2 traces the international and domestic drivers influencing each country and reviews the participation of Indigenous and local communities in the development and implementation of each regime. The chapter identifies the common features of the two regimes that shape the subsequent comparative analysis. Both countries have established access and benefit-sharing regimes to achieve their objectives, supported by the use of databases to safeguard and defend traditional knowledge. Furthermore, India and Peru have also established institutions and associated funds that support the governance of their respective regimes for the protection of traditional knowledge. These common features are then examined in greater detail in the three subsequent chapters, commencing with a comparative analysis of the institutions and funds established in India and Peru in Chapter 3.

Chapter 3 presents an analysis of the role and operation of the national competent authorities established in India and Peru to regulate traditional knowledge, along with other institutions at the regional or local level that play a role in governing access to and use of traditional knowledge. The chapter analyses the function and funding of each institution and reviews each institution within the framework of self-determination to determine the level of Indigenous involvement in each institution. Chapter 4 reviews and critiques the laws and regulations of India and Peru relating to access to, and sharing of, benefits arising out of the utilisation of traditional knowledge. The chapter commences with a comparative analysis of the procedures for obtaining access to traditional knowledge and is followed by a comparative analysis of the benefit-sharing provisions of each country. Chapter 4 identifies the

property, UN Doc E/C.12/2001/15 (14 December 2001) 3; Rosemary J. Coombe, above n 283,91 . 
relative strengths and weaknesses of each access and benefit-sharing regime and assesses their effectiveness in fulfilling the requirements of the CBD and Nagoya Protocol. Chapter 5 sets out a comparative analysis of the national and local traditional knowledge databases of India and Peru, with an emphasis on the purpose of each database, the related structure and access models, and the administration of databases in each country. The chapter reviews the operation of each database including the outcomes arising from or associated with each collection.

Following the comparative analysis set out in Chapters 2 to 5 , the book identifies the key lessons relevant to the design and implementation of nationally consistent regimes for the protection of traditional knowledge across each of the four themes used to frame the comparative analysis. Chapter 6 uses Australia as an illustrative example of how these lessons may be applied in a domestic context. While Chapter 6 identifies and discusses key lessons arising out of the experience of India and Peru and the application of these lessons in the context of Australia, the book does not set out all the elements of a proposed regime for the protection of traditional knowledge. The ideas presented in Chapter 6 are intended to stimulate discussion and may be used by Indigenous and local peoples, including Aboriginal and Torres Strait Islander peoples in Australia, in making decisions regarding the protection of traditional knowledge within a framework of self-determination. The chapter concludes that a range of legal tools may be used to protect traditional knowledge, and based on principles of self-determination, prior informed consent, and mutually agreed terms, may act as a form of corrective justice to return to Indigenous and local communities institutions that affirm Indigenous culture, values, and practices. 